\title{
NATIONAL BUREAU OF STANDARDS REPORT 7009
}

\author{
INTERIM REPORT \\ ON \\ CHIIIED AIR DISTRIBUTION \\ IN REFRIGERATED TRAIIERS \\ $\begin{array}{ll} & \text { by } \\ \text { P. R. Achenbach } \\ \text { J. W. Grimes } \\ \text { R. J. Dockery }\end{array}$
}

Report to

Transportation Research Branch

Transportation and Facilities Research Division

Agricultural Marketing Service

U.S. Department of Agriculture

\section{NBS}

U. S. DEPARTMENT OF COMMERCE NATIONAL BUREAU OF STANDARDS 


\section{THE NATIONAL BUREAU OF STANDARDS}

\section{Functions and Activities}

The functions of the National Bureau of Standards are set forth in the Act of Congress, March 3, 1901, as annended by Congress in Public I,aw 619, 1950. These include the development and maintenance of the national standards of measurement and the provision of means and methods for making measurements consistent with these standards; the determination of physical constants and properties of inaterials; the development of methods and instruments for testing inaterials, devices, and struetures; advisory serviees to government agencies on scientific and technical problems; invention and development of devices to serve special needs of the Government; and the developinent of standard practiees, codes, and specifications. The work includes basic and applied research, development, engineering, ingtrumentation, testing, evaluation, ealibration serviees, and various consultation and information serviees. Researeh projects are also performed for other government agencies when the work relates to and supplements the basie program of the Bureau or when the Bureau's unique competence is required. The scope of aetivities is suggested by the listing of divisions and seetions on the inside of the baek cover.

\section{Publications}

The results of the Bureau's work take the form of either actual equipment and devices or published papers. These papers appear either in the Burean's own series of publications or in the journals of professional and scientifie societies. The Bureau itself publishes three periodicals available from the Govermuent Printing Office: The Journal of Research, published in four reparate sections, presents complete scientific and technical palpers; the Technical News Bulletin presents smnmary and preliminary reports on work in progress; and Basic Radio Propagation Predictions provides data for deterinining the best frequencies to use for radio communications throughout the world. There are also five series of nonpcriodical publications: Monographs, Applied Mathenatic's Series, Handbooks, Miscellaneous Publieations, and Technical Notes.

Information on the Bureau's publications can be found in NBS Circular 460, Publications of line: National Bureau of Standards $(\$ 1.25)$ and its Supplement $(\$ 1.50)$, available from the Superintendent of Doeuments, Governınent Printing Office, Washington 25, D.C. 


\title{
NATIONAL BUREAU OF STANDARDS REPORT
} MBS PROJECT

1003-12-10131 $1003-12-10434$

NBS REPORT 7009

\author{
November 4, 1960 \\ INTERIM REPORT \\ ON \\ CHILLED AIR DISTRIBUTION \\ IN REFRIGERATED TRAILERS

$$
\begin{aligned}
& \text { P. R. Achenbach, } \\
& \text { J. W. Grimes, } \\
& \text { and } \text { J. Dockery }
\end{aligned}
$$ \\ Mechan1cal Systems Sect1on \\ Bullding Research Division
}

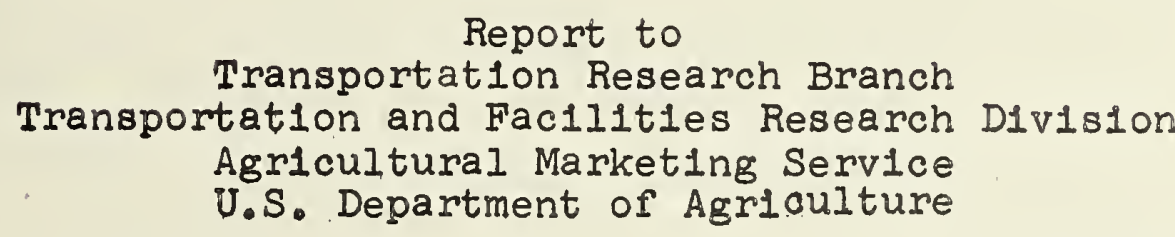

IMPORTANT. NOTICE

NATIONAL BUREAU OF ST/ Intended for use within the I to additional ovaluation and $r i$ Ilsting of this Report, elther I the Office of the Director, Nal however, by the Government.: so reproduce idditional coples gress accounting documents ally published it is subjected productlon, or open-llterature in is obtalned In writing from uch permission ls not needed, epared If that agency wishes
Approved for public release by the Director of the National Institute of Standards and Technology (NIST) on October 9, 2015.

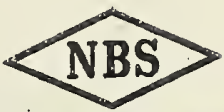




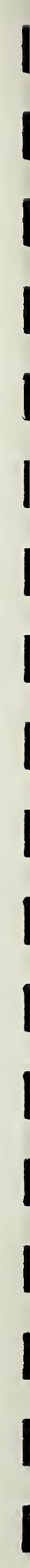




\section{INTERIM REPORT \\ ON}

CHILLED AIR DISTRIBUTION IN REFRIGERATED TRAILERS

\section{by}

P. R. Achenbach, J. W. Grimes and R. J. Dockery

\section{INTRODUCTION}

As a supplement to the study of testing and rating methods for refrigerated trallers conducted by the National Bureau of Standards in cooperation with the U.S. Department of Agriculture, the Quartermaster Research and Engineering Command, and the TruckTrailer Manufacturers Association, an investigation was undertaken of methods by which the distribution of chilled air around the cargo in such trailers could be made more effective in maintaining the desired temperatures in the entire cargo. This study is being sponsored jointly by the U.S. Department of Agriculture and the National Bureau of Standards under USDA Agreement No. 12-25-010-978, and amendments.

\section{PROJECT OUTLINE}

A broad outline of the work to be carried out in this study was included in the agreement. Work on the project began in January 1959 and it was anticipated that it would continue for at least 3 years. The study was outlined as follows:

Part I - Devise instrumentation for measuring air velocity and temperature patterns around frozen loads, and temperatures of frozen products in refrigerated trailers.

A. Devise thermocouple pattern for evaluating temperature distribution of air, product, and cargo surface in a refrigerated load.

B. Study instruments of probe type for measurements of air velocities in the range from 5-100 fpm at multiple stations in a refrigerated load - these measurements will not necessarily be used on the road. Buy or build them.

C. Study instruments for measuring the heat transfer into or out of frozen products during cyclic operation of the refrigerating unit during laboratory and road tests. 
Part II - Study air distribution and temperatures in loaded trailers in laboratory, using floor racks and wall spacers.

A. Two plug-type refrigerating units will be modifled to permit heat gain measurements in trailers during laboratory and over-the-road studies.

B. Heat leakage tests on both trailers.

C. Internal air distribution under steady operation at $100^{\circ} \mathrm{F}$, and $50 \%$ Relative Humidity ambient.

1. Free air delivery and free return

a. Flat floor and wall spacers

b. Extruded floor and wall spacers

c. Floor racks and wall spacers.

2. Free air delivery and controlled return

a. Extruded floor and wall spacers

b. Floor racks and wall spacers.

3. Controlled air delivery and free return

a. Extruded floor and wall spaces

b. Floor racks and wall spaces.

D. Internal air distribution under cyclic operation

1. Free air delivery and free return

2. Free air delivery and controlled return

3. Controlled air delivery and free return.

E. Study placement of control device under cyclic conditions and the effect of starting and stopping the fans.

Part III - Conduct test with steady and cyciic operation in the laboratory using a trailer altered for cold wall construction.

Part IV. - Compare conventional and modified air distribution systems during road tests with frozen load in identical trailers.

Part V - Study practicability of shipping subcooled frozen foods in unrefrigerated, insulated vehicles. 
Part VI - Study air distribution and loading methods required to absorb heat of evolution in trailers.

Part VII - Road tests of trailers studied in Part VI.

This interim report describes the work that has been done under Part I ( $A, B$, and $C$ ) and Part II ( $, C 1, C 2$, and $C 3$ ).

\section{TEST APPARATUS AND EQUIPMENT}

The equipment for this study included two nominal 35-foot trailers for low-temperature service furnished by two trailer manufacturers, a heat-sink apparatus for measuring the cooling load during the tests, a simulated frozen cargo, a thermocouple system for measuring temperatures in the load, heat flow meters for measuring heat exchange between the cargo and its surroundings, and specially-designed anemometers for measuring the air velocity in the narrow air spaces surrounding the cargo.

A cargo of real frozen food was impractical for these studies because it would have spoiled during the repeated freezing and thawing cycles necessitated by the changes in test conditions. Sweeping compound, consisting of a mixture of sand, sawdust, and mineral oil, was chosen as a simulated load because it was found to be the most economical material available having a density and specific heat near to that for packaged frozen food.

Cardboard boxes of two sizes, $12 \times 12 \times 12$ inches and $12 \times 12 \times 6$ inches, were used to permit the desired type of loading pattern. Each box was lined with aluminum foil to prevent absorption of the mineral oil by the cardboard, and then filled with the sweeping compound. The larger boxes weighed $40 \mathrm{lb}$ after filling, and the smaller ones about half as much. The specific heat of the sweeping compound was computed to be approximately $0.35 \mathrm{Btu} / \mathrm{lb}\left({ }^{\circ} \mathrm{F}\right)$. The entire load was comprised of 810 large boxes and 135 small boxes totaling approximately $35,000 \mathrm{lb}$ in weight. The boxes were placed in five layers, six rows wide, and in 27 stacks from front to rear of the trailer as indicated in Figure 1. The small boxes were used to provide the desired width of air space at the sidewalls of the trailer.

The cooling unit inside the trailer was mounted in the front end and it discharged chilled air toward the rear over the load. A plywood partition was placed between the cooling unit and the load, and openings were made in the partition for the supply air and return air. The opening for the supply air measured $12 \times 12$ inches and was in the center of the partition with the top edge of 
the opening 6 inches from the celling of the trailer. Two return air openings, $12 \times 14$ inches, with adjustable doors were provided in the partition above the level of the top of the load, one opening on either side of the supply air opening. Alternate return air openings were cut in the partition in the form of slots adjacent to the sidewalls in addition to the openings provided underneath the partition by the grooves in the corrugated floor. The slot at each side of the partition was 38 inches high and I inch wide, and the grooves in the floor comprised an area of about 22 square inches. The cooling unit circulated air at a rate of approximately $1,500 \mathrm{cfm}$ with the two doors for return air open and with no frost on the cooling coil.

\subsection{Thermocouple System}

Thirty of the one-cubic-foot boxes of the simulated load were equipped with thermocouples to determine the temperature pattern in the cargo. The thirty boxes were located in the 1st, 7 th, 14th, 21 st, and 27 th stacks of boxes, counting from the front of the trailer; in the bottom, middle, and top layers of the load; with half of the total being adjacent to one wall of the trailer and the other half being placed along the center line of the load. The locations of these boxes are indicated in the three views of the trailer in Figure 1. A thermocouple was placed in the center of each of the 30 boxes, and additional thermocouples were affixed to the inside and outside of the cardboard walls of the boxes 10cated at the periphery of the load. Two or three such pairs of surface thermocouples were used in the boxes located at a corner of the load, one pair on each exterior exposure of these boxes. The location of the thermocouples in a typical box with 3 exposures at a corner of the load. Nilustrated in Figure 2.

Other thermocouples were located in the discharge air opening, in the return air opening to the cooling coil, in the air spaces surrounding the load, and near the sidewall slots in the partition separating the cooling coll and the cargo. Air temperatures were also measured on the exterior of the trailer at each corner.

\subsection{Heat Flow Meter System}

Nine heat flow meters were placed in six of the boxes of sweeping compound to measure the rate of heat exchange between the load and the surrounding air at selected places. The locations for the heat flow meters are shown in Figure 1 . The heat flow meters were placed between the sweeping compound and the foll lining of the boxes, paraliel to the face of the box and at the center of the face. The four boxes at the top center, bottom center, rear center, and sidewall center of the load were 
equipped with one heat flow meter each; whereas the other two boxes, located at corners of the load, were equipped with two and three heat flow meters, respectively. The location of the three meters in one box is illustrated in Figure 2. The locations of the meters in the load are identifled in Table 1.

\section{Table 1}

Heat Flow Meter Locations

\begin{tabular}{ccll} 
Meter No. & Stack No. & Layer & Row \\
\cline { 2 - 4 } I, 2 & 14 & Bottom & Sidewall \\
3 & 14 & Middle & Sidewall \\
4 & 14 & Bottom & Center \\
5 & 14 & Top & Center \\
$6,7,8$ & 27 & Bottom & Sidewall \\
9 & 27 & Middle & Center
\end{tabular}

Each heat flow meter was separately calibrated at temperatures of $84^{\circ} \mathrm{F}$ and $64^{\circ} \mathrm{F}$ to establish the magnitude of the temperature correction. The sensitivity of the various meters ranged from about 7 to $8 \mathrm{Btu} / \mathrm{hr}(\mathrm{ft})^{2}$ per mililvolt of emf.

\subsection{Air Flow Meter System}

A multiple-element air flow meter was designed, constructed, and calibrated for remote measurement of air flow rates in small passages at 20 different stations. The sensing elements employed the thermocouple anemometer principle and were designed to fit into a passage of 1 square inch cross section with a minimum of obstruction to the air flow. Figure 3 is a schematic drawing of the principal components of the meter and the wiring circuits. By proper selection of the heating current for the sensing elements in the range from 7 to 22 microamperes, the meter could be used to measure air flow rates in the range from 10 to $1,000 \mathrm{fpm}$. Twenty-one of these elements were constructed and calibrated. Figure 4 is an average of the calibration curves for the elements.

Sensing elements were installed at 8 stations in the air space between the load and one sidewall, at one station in the air space between the load and the back wall of the trailer, at 8 stations in the grooves of the floor construction, and at 3 stations above the top of the load. These stations are indicated in the three views of Figure 1. Figure 5 shows one of the air flow devices located in a groove of the trailer floor. Six of the elements in the air space at the side of the load were installed so they could 
be rotated about a horizontal axis from outside the trailer to determine the direction of maximum air velocity in the space. Figure 6 is an exterior view of one side of the trailer showing the air flow devices projecting through the wall.

\section{TEST PROCEDURE}

A heat leakage test was made of the empty trailer. For this purpose, the interior temperature was maintained at $0^{\circ} \mathrm{F}$ and the exterior conditions were maintained at a dry bulb temperature of $100^{\circ}$ and a relative humidity of 50 percent for a period of 50 hours after steady conditions were attained. The change in weight of the trailer was also observed during this period.

The full load of simulated frozen cargo was allowed to come to steady state temperature conditions for 8 different patterns of air circulation inside the trailer. The return air temperature at the cooling coil was controlled at $0^{\circ} \mathrm{F}$ and the ambient conditions were maintained at a temperature of $100^{\circ} \mathrm{F}$ and a relative humidity of 50 percent. The variations in air distribution control are described in Table 2. Each test was continued for approximately a week to allow the load to attain a steady temperature representative of the test conditions. The cooling coil was defrosted whenever a return air temperature of $0^{\circ} \mathrm{F}$ could no longer be maintained. Warm brine was circulated through the cooling coil and the blower was shut off during the defrosting period.

\section{TEST RESUITS}

5.1 Heat Transmission of the Empty Trailer

The average heat transmission of the empty trailer during the 50-hour test at steady conditions in the laboratory was $8,600 \mathrm{Btu} / \mathrm{hr}$, or $86.0 \mathrm{Btu} / \mathrm{hr}$ (degree temperature difference) for the conditions previously described. This value is nearly I, 000 Btu/hr less than was observed on this same vehicle about 2 years earlier. However, openings through the exterior skin of the trailer that were revealed by a smoke test were sealed before making the latter measurements, so a reduction in heat transfer was expected. The average weight gain rate during the test period was $0.42 \mathrm{Ib} / \mathrm{hr}$ whereas the rate of weight gain during the earlier tests was more than twice this value.

5.2 Temperature Distribution in the Load

The steady state temperature distribution observed in the simulated load for the 8 air distribution plans summarized in Table 2 are shown graphically in Figures 7 to 14. The essential 


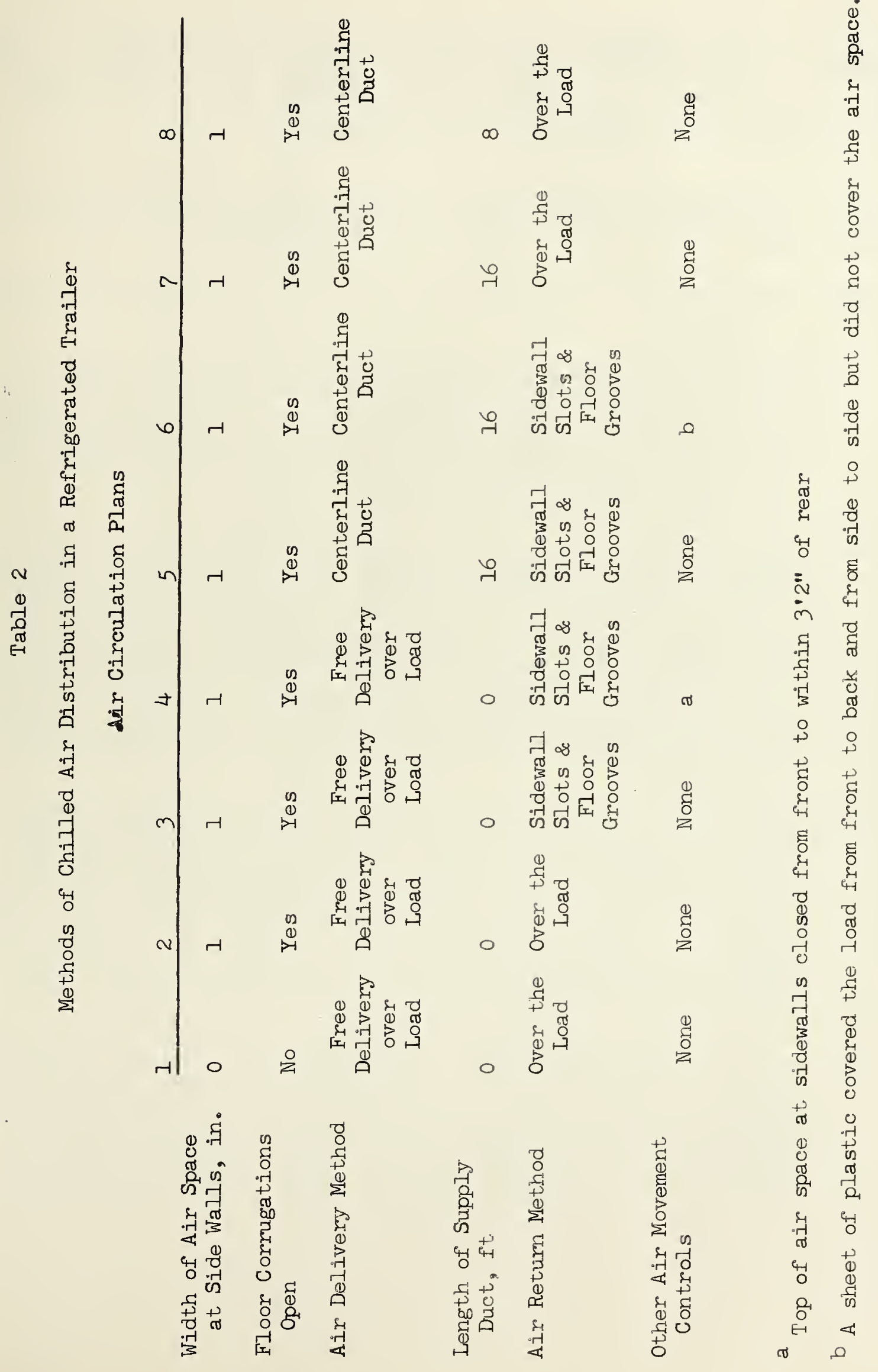


features of each distribution plan are illustrated in the diagrams at the top of the figures. The figures show the variation in load temperature from front to back of the trailer; along one sidewall and at the center of the load; for the bottom, middle, and top layers of the load. The average air temperature at the inlet to the cooling coll is also shown in the figures.

The temperatures in the load are also summarized in Table 3 for the 8 different air distribution plans on a stack average, layer average, row average, and load average basis.

The following conclusions are indicated by the data in Figures 7 to 14 and Table 3 .

1. Without a1r spaces at the sidewalls and floor, as in PIan 1 , the boxes on the floor in the back half of the trailer reached a steady state temperature of about $50^{\circ} \mathrm{F}$, whereas those in the top layer at the rear reached a steady state temperature of about $20^{\circ} \mathrm{F}$. The average temperature for the entire load was about $25^{\circ} \mathrm{F}$.

2. Free delivery of the chilled air over the load from the cooling unit did not adequately cool the cargo at the rear of the trailer with a l-inch air space at the sidewalls and with the floor corrugations open. For these conditions, the temperature difference between the cargo at the front and rear of the traller was about $30^{\circ} \mathrm{F}$ for either direct return of the air over the load or return of the air through the sidewall slots and floor grooves. These results are shown in Figures 8 and 9 for air distribution Plans 2 and 3.

3. The average temperature of the boxes was progressively higher from the top to the bottom of the load for every air circulation plan tried. The temperature difference between the top and bottom layers on layer average basis was $30.9^{\circ} \mathrm{F}$ for Plan 1 and ranged from 12.7 to $17.9^{\circ} \mathrm{F}$ for the other 7 plans with air spaces around the load. This temperature distribution indicates that the l-inch air space at the sidewalls and the open floor grooves did not permit enough air circulation around the load.

4. An open-end supply duct, centered over the load, either 8 feet or 16 feet long, cooled the boxes at the rear of the trailer to within 3 to 5 degrees of the temperature ob-served in those at the front. The warmest boxes were at midlength of the trailer at all levels when the supply duct was used. This temperature distribution pattern 


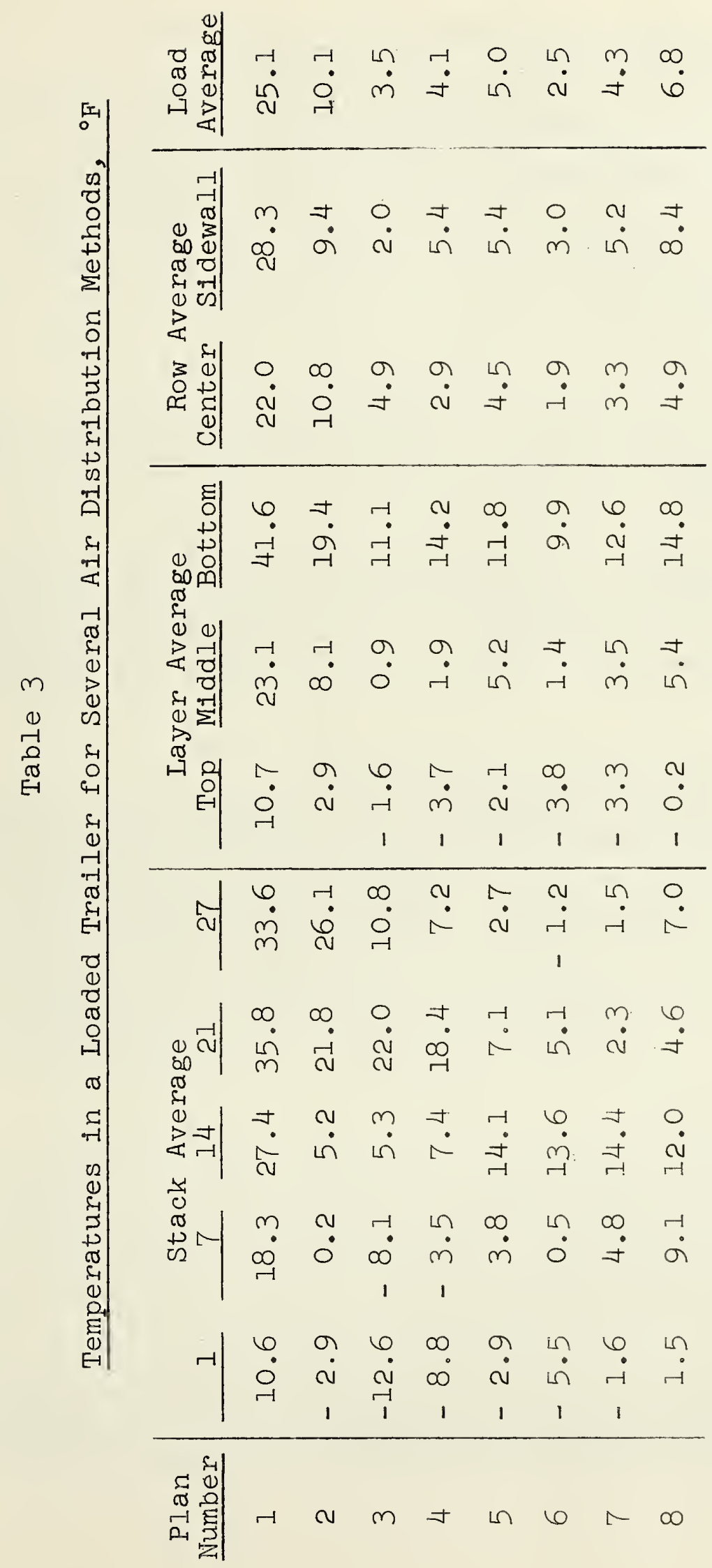


indicates that the supply duct should have had side outlets near midlength of the trailer.

5. A comparison of the test results for air circulation Plans 5 and 6 indicates that placing a plastic cover over the load was accompanied by a reduction in average load temperature of 2.5 degrees. The lowest average load temperatures and the lowest box temperatures at the rear of the trailer, in stack 27, for all 8 plans were obtained with the plastic cover over the load in Plan 6, but the magnitude of difference with respect to Plans 5 and 7 was not large.

6. Table 3 shows that the lowest average temperatures for the load were observed for air distribution Plans 3 and 6 , but these were only slightly lower than the average temperatures for Plans 4, 5, and 7 .

7. The difference in temperature between the row of boxes at the center of the load and one at the sidewalls was $6.3^{\circ} \mathrm{F}$ on the average for Plan 1 , without air spaces around the load; but this average difference ranged between $0.9^{\circ} \mathrm{F}$ and $3.5^{\circ} \mathrm{F}$ for all the other air circulation plans.

\subsection{Heat Transfer to and from the Load}

The heat transfer between the load and the air or trailer surfaces in contact with it was seldom steady during any of the 8 tests. The average values at the 9 heat flow meter locations after the load had approached a steady state, ranged from 0 to about $1.7 \mathrm{Btu} / \mathrm{hr}(\mathrm{ft})^{2}$. However, the chilled air circulation decreased as the amount of frost on the cooling coil increased, accompanied by a cyclic change and reversal of the direction of the heat exchange between the load and the air at the stations most readily affected by the air circulation. Extreme values of 2 to $3 \mathrm{Btu} / \mathrm{hr}(\mathrm{ft})^{2}$ in either direction were not uncommon at some heat flow meter locations.

The three heat flow meters adjacent to the floor of the trailer always indicated heat flow into the load regardiess of the frost conditions on the cooling coil and the method of air circulation used. The heat flow meters on the top center and center of the side of the load showed that the air was cooling the load most of the time, but that reversals of heat flow occurred occasionally at these stations between one defrosting and the next.

The indications of the several heat flow meters affixed to the load are shown in Figures 15 and 16 for test 4 and Figures 17 and 18 for test 7 for a period of 100 hours or more in each case. 
Heat flow meters $3,4,5$, and 9 indicated the heat flow rate at the centers of four of the exposed areas of the load and meters $1,2,6,7$, and 8 indicated the heat flow at corner positions in the load. As illustrated by these figures, the heat exchange between the load and the air varied more rapidly and reversed direction more often when the chilled air was returned around the load than when it was returned over the load.

The projected surfaces of the top and bottom of the load were about 175 square feet each, and that of either side about 135 square feet. If it is assumed that the heat flow indicated at the center of each of these areas by the heat flow meter was representative of that entire load surface, extreme values of heat transfer approximating $450 \mathrm{Btu} / \mathrm{hr}$ in either direction occurred at times between the top of the load and the chilled air during test 4 . Likewise, heat was transferred from the floor to the load at a fairly steady rate of about $175 \mathrm{Btu} / \mathrm{hr}$ during the same test. The heat exchange rates between the load and the chilled air were significantly lower during test 7 as indicated by Figures 17 and 18 . Average values of about $0.5 \mathrm{Btu} / \mathrm{hr}(\mathrm{ft})^{2}$ in opposite directions occurred at top center and back center of the load, and the rates were even lower at the floor and sidewall.

5.4 Cooling Load of Loaded Trailer

The total cooling effect produced by the cooling coil inside the trailer was computed from the measured brine flow rate and the temperature rise of the brine between inlet and outlet of the trailer. This gross cooling capacity was reduced by the heat equivalent of the electric energy used by the blower motor and the electric reheat used to control the return air temperature to the cooling coll. The net cooling effect, so obtained, was the algebraic sum of the heat transmission through the trailer walls, floor, and roof and any heat transfer between the chilled air and the cargo.

The net cooling effect computed for the period of analysis when the cargo was at a nominal steady state condition was about $5,300 \mathrm{Btu} / \mathrm{hr}$ for PIan 1 when the cargo was in contact with the walls and floor of the trailer, and ranged from 6,800 to 9,600 Btu/hr for the other 7 plans of air circulation for ambient conditions of $100^{\circ} \mathrm{F}$ dry bulb temperature and 50\% relative humidity.

In each test, the return air temperature to the cooling coil was controlled at $0^{\circ} \mathrm{F}$ within a tolerance of about $\pm I$ degree. It was observed that the net cooling effect was not steady between defrosting periods. As frost accumulated on the cooling coil, the air circulation rate decreased and the temperature of the chilled air leaving the cooling coil had to be lowered to maintain 
a constant return air temperature. Thus the portions of the load near to the cooling coil discharge gradually became colder as the cooling coll became loaded with frost. It is probable that the mean temperature difference between inside and outside the trailer also increased somewhat as the cooling coll became loaded with frost. Further analysis of the temperature changes in the load, change in chilled air temperature, and quantity will be required to correlate these variables with changes in the net cooling load.

\section{FUTURE TESTS}

In future tests, floor racks on top of the extruded trailer floor and air spaces at the sides and rear of the load up to 3 inches in width will be used to increase the air circulation around the load. The return air openings in the partition between the cooling coil and the load will be enlarged at the floor and walls to reduce the restriction to air flow. A trailer will be modified to provide built-in channels for air circulation around the load. The tests will be directed toward a determination of the essential requirements with respect to supply ducts, floor racks, and air spaces around the load for adequate cooling of all parts of a frozen cargo. 


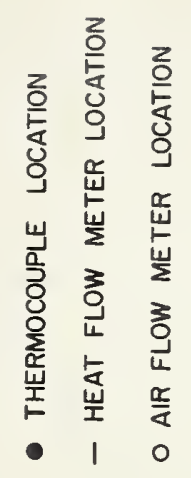
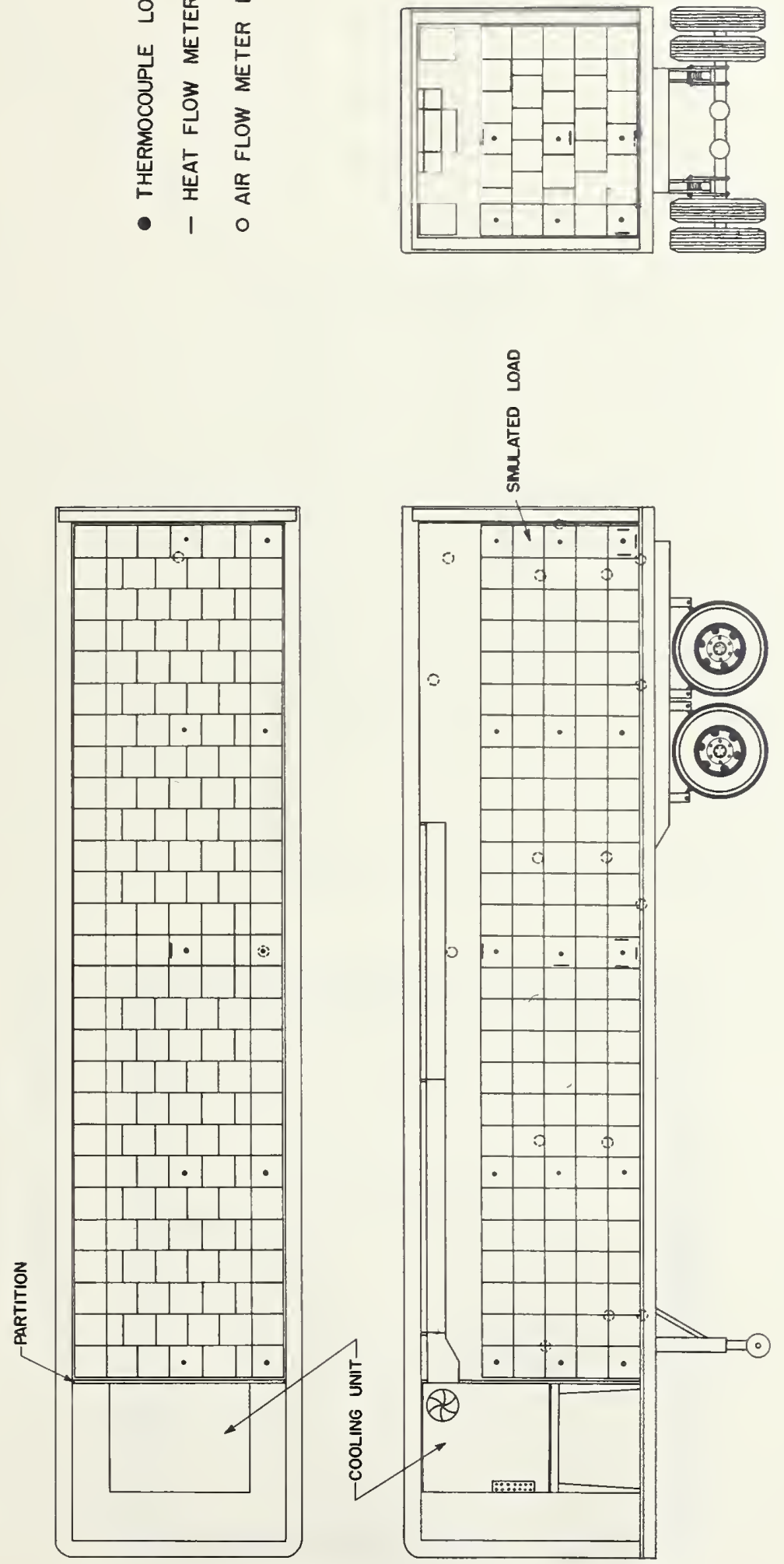

ㄱ
0
5
5
5
5
7
II
1 
I 


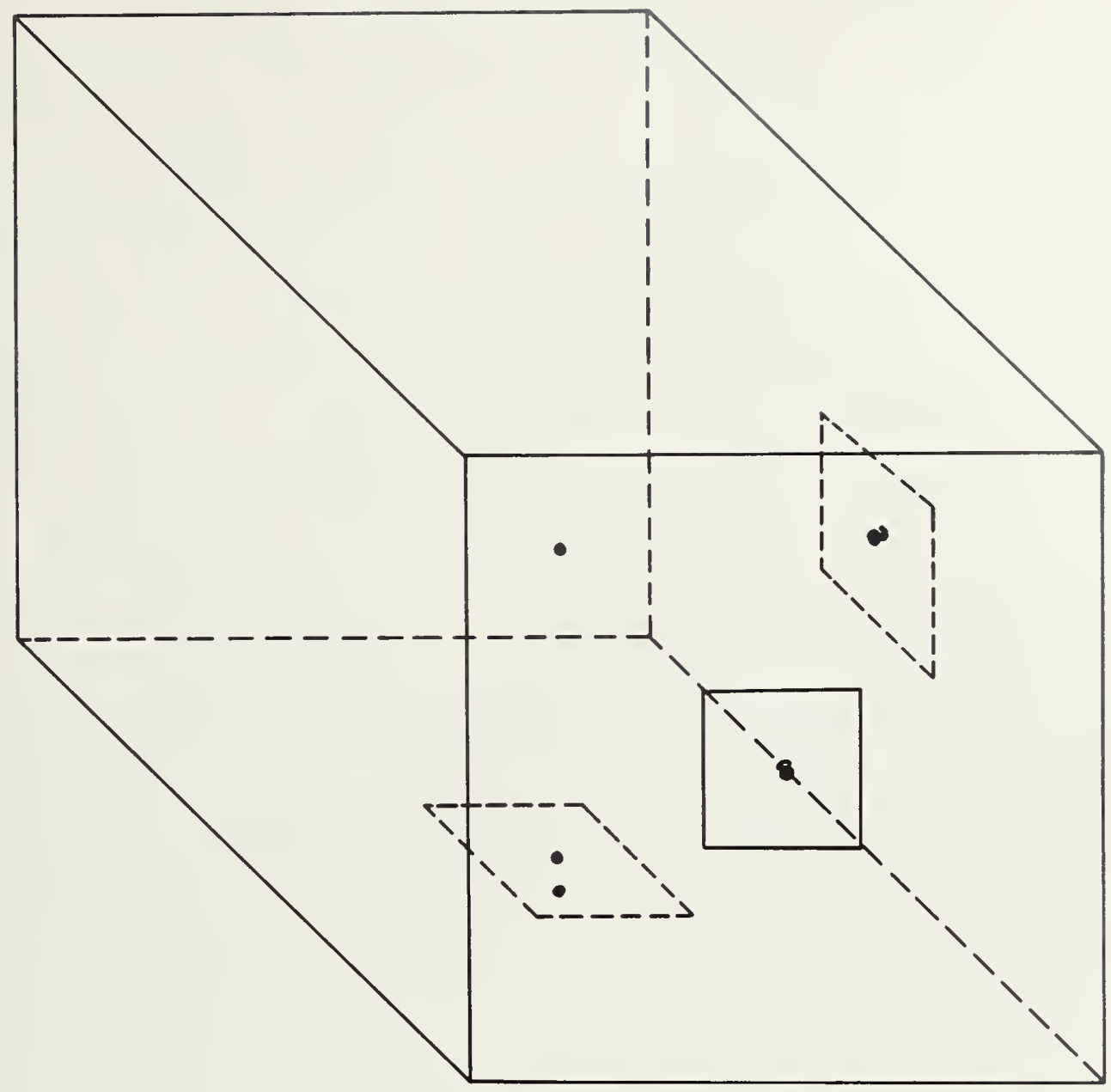

0
0
5
5
5
5
51
51

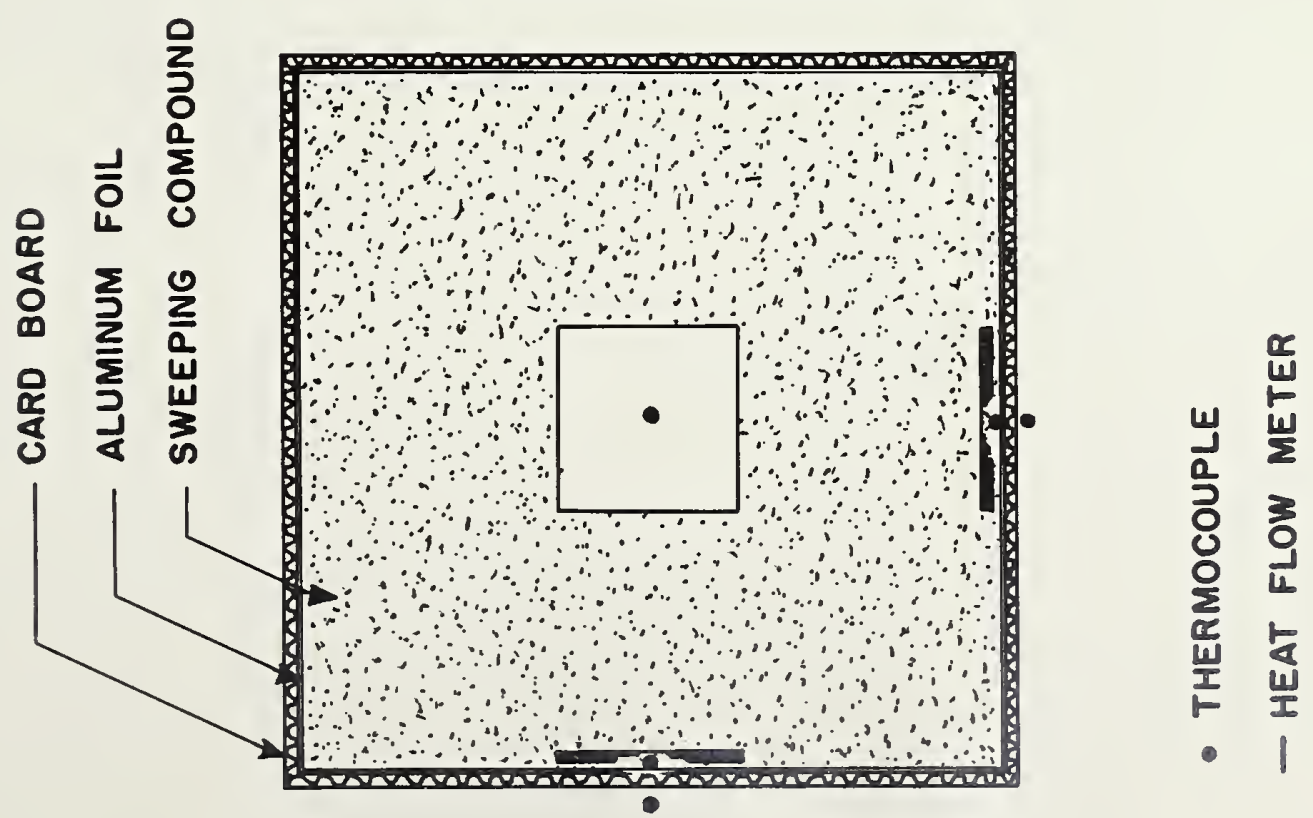




$$
29262^{2}
$$


THERMOCOUPLE ANNEMOMETER SCHEMATIC DIAGRAM

TRANSF.

$110: 5 \mathrm{~V}$.

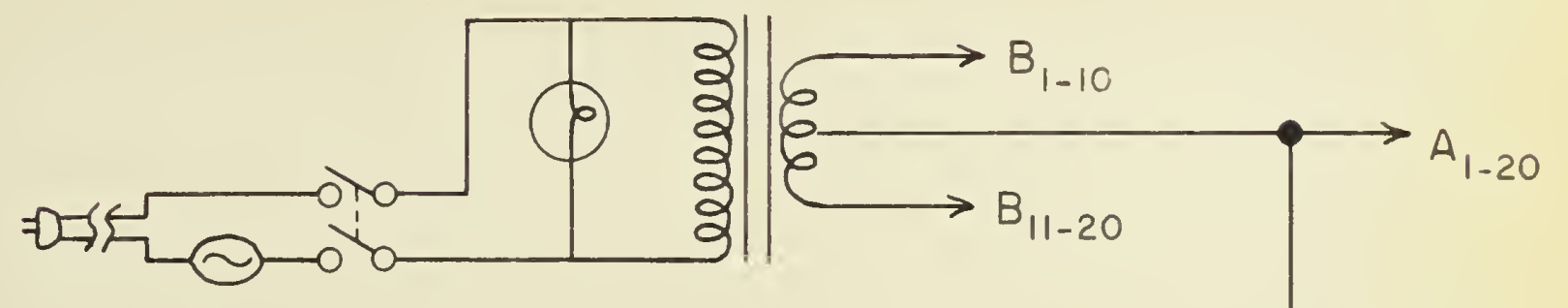

20 PROBES

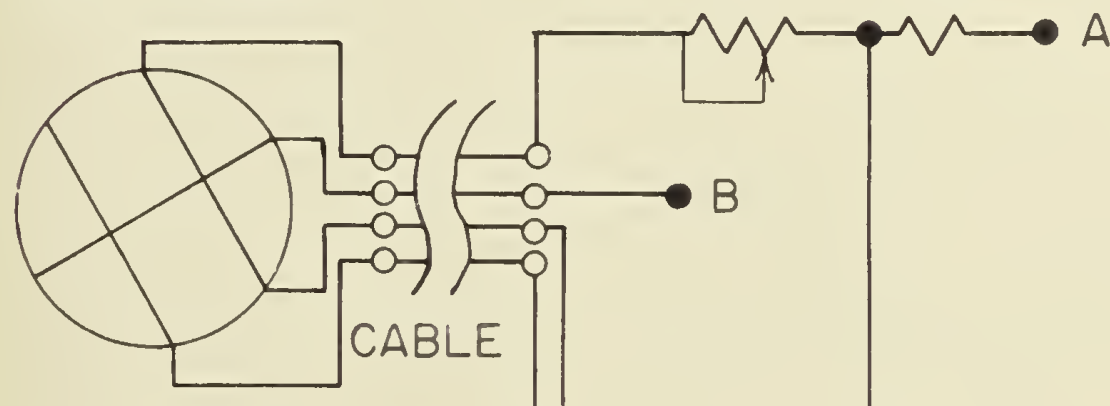

$100 \quad 25$

20 POS., 3 WAFERS SELECTOR SWITCH

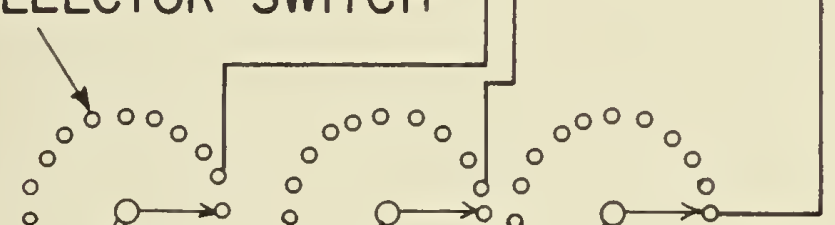

O - 3OUA

- IN 455

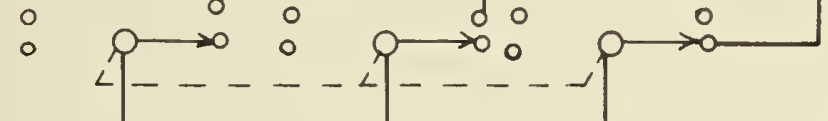

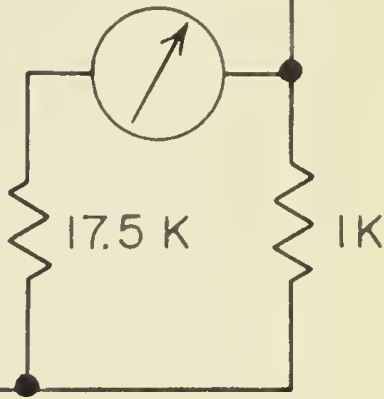

$\rightarrow \quad 0$

$$
\delta_{--p}
$$

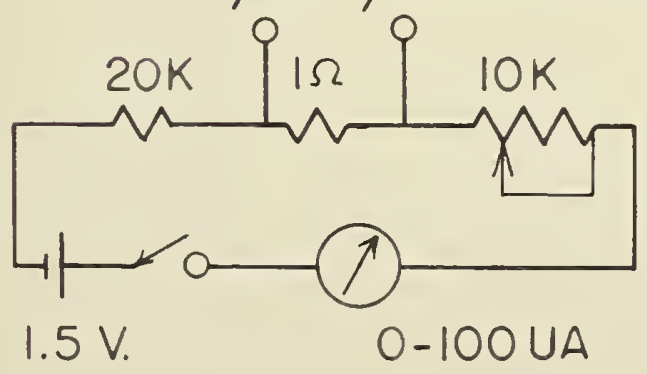

KINTEL MOD.204A DC AMPLIFIER

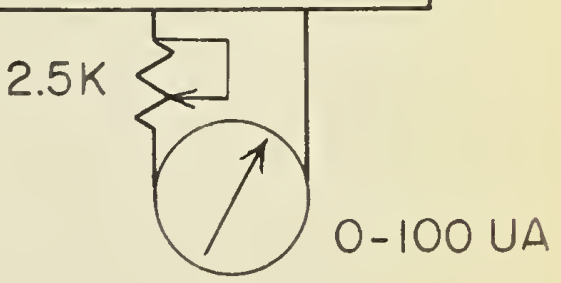





\section{AVG. OF 21 ANEMOMETER PROBES}

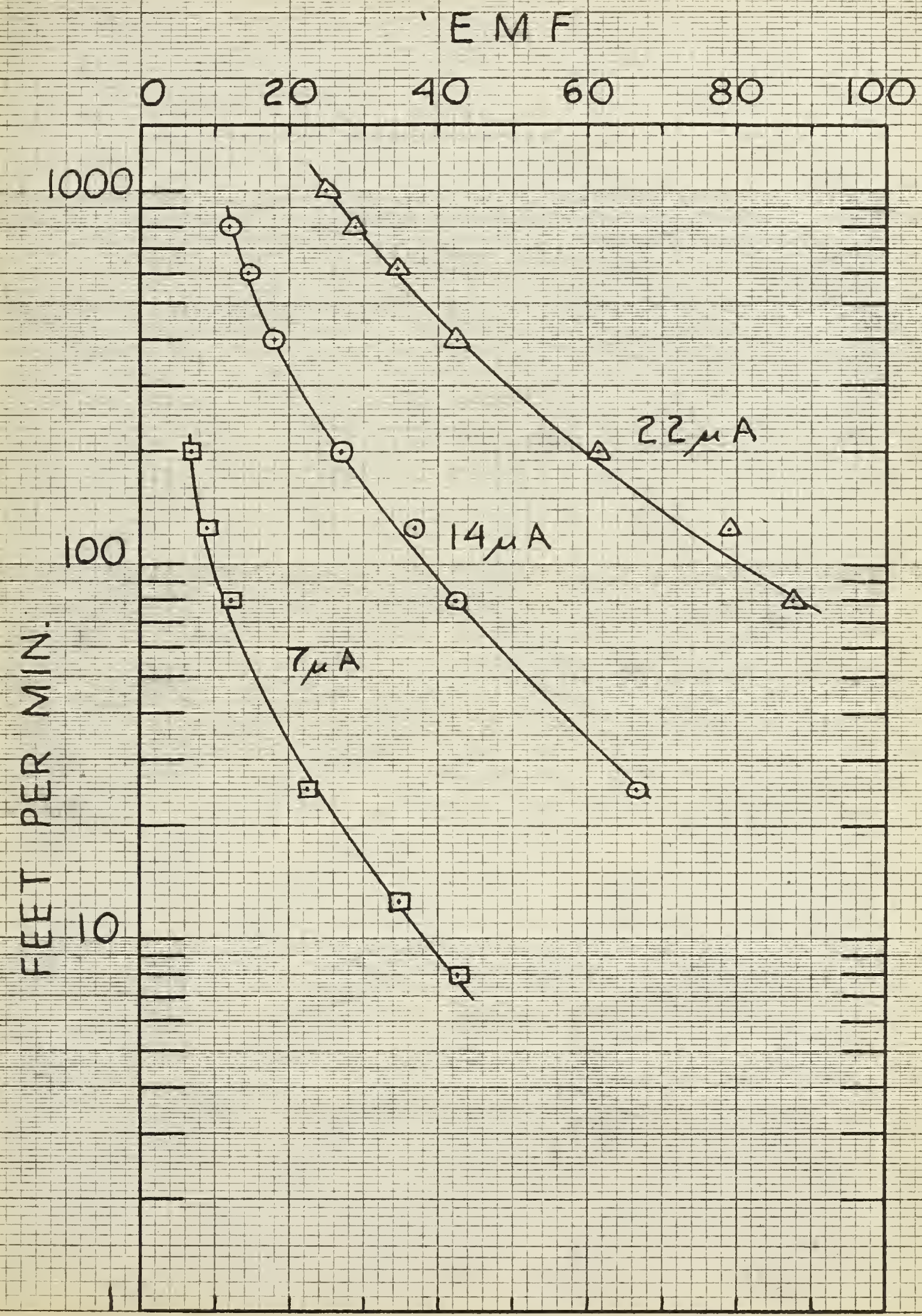





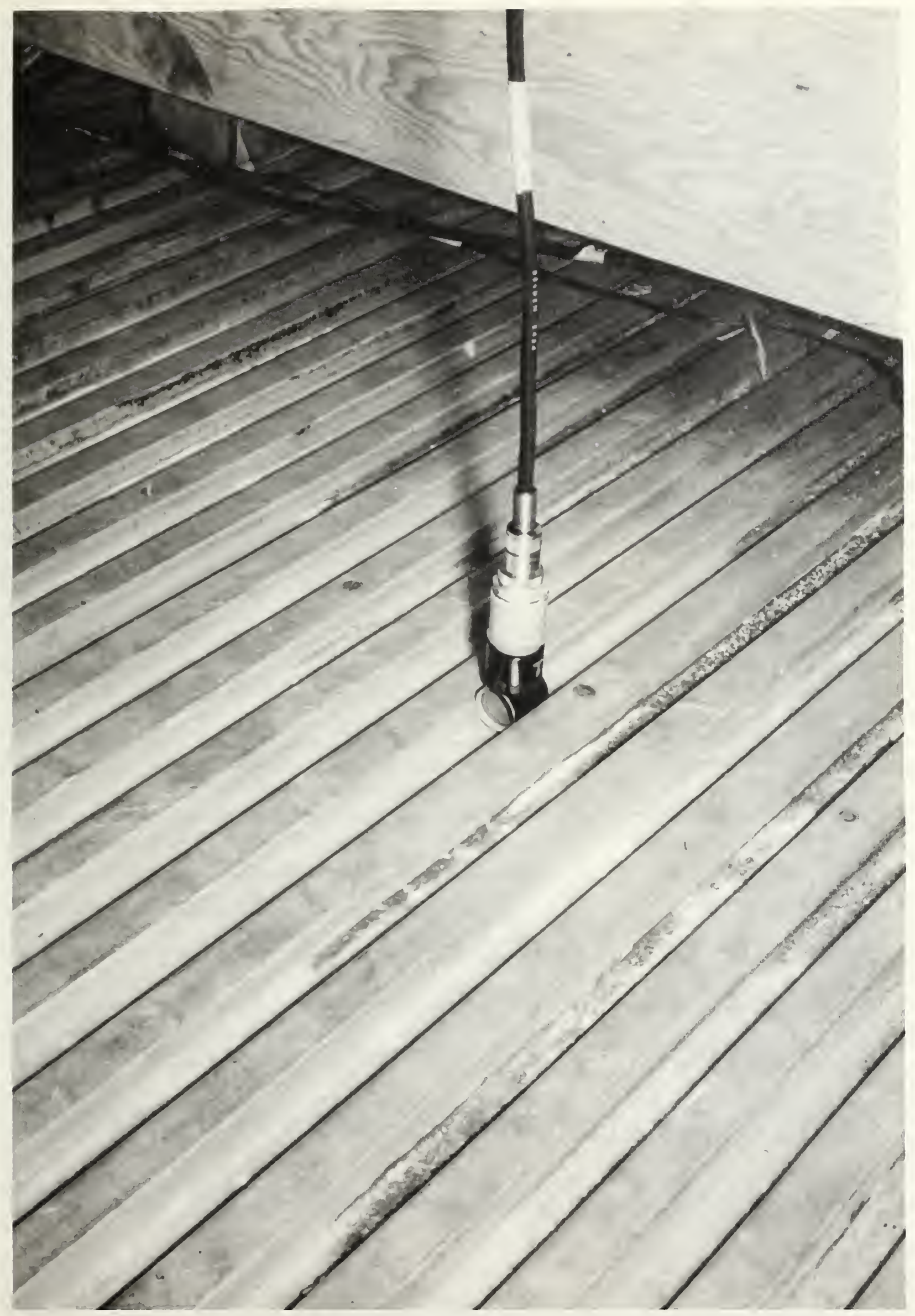




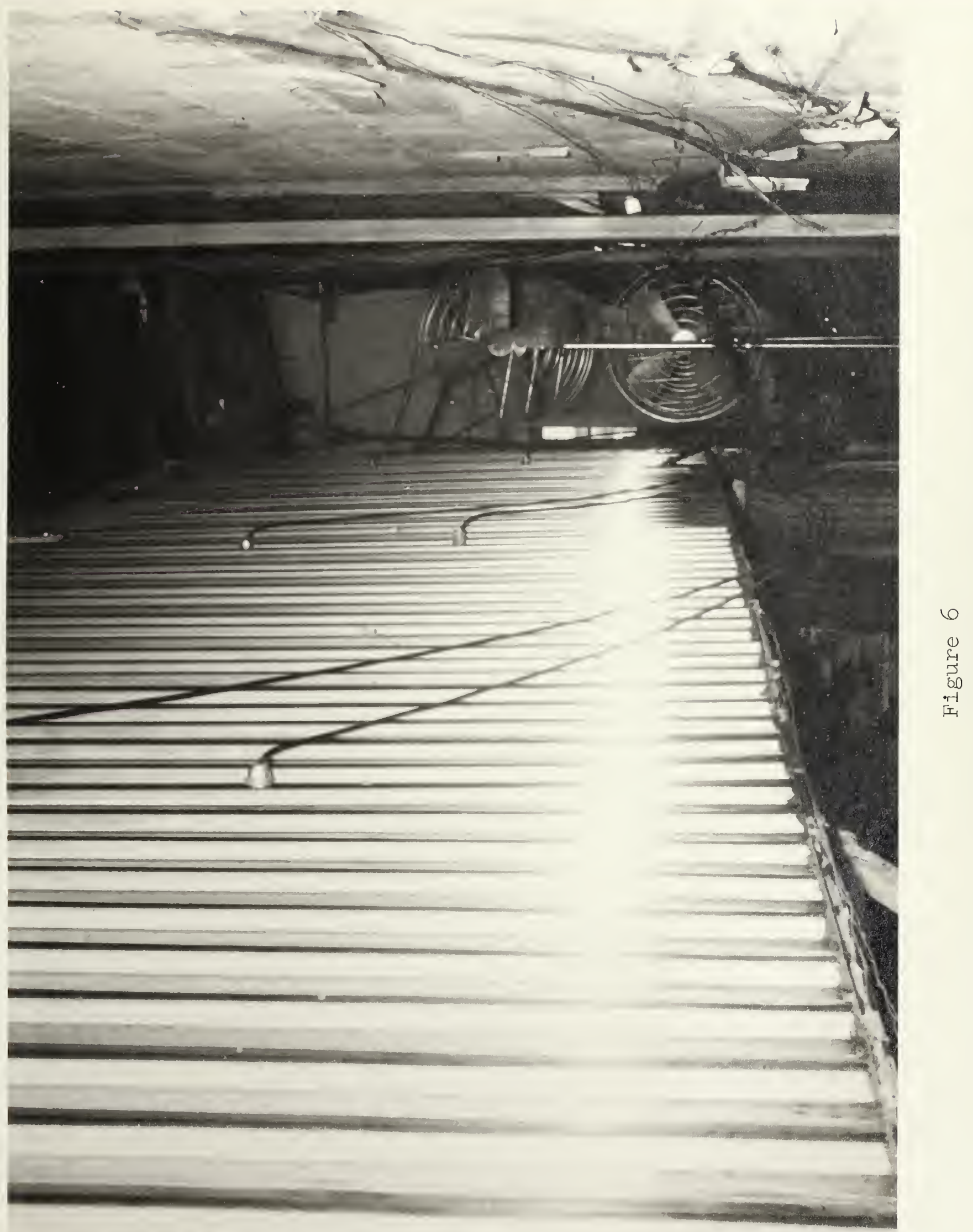





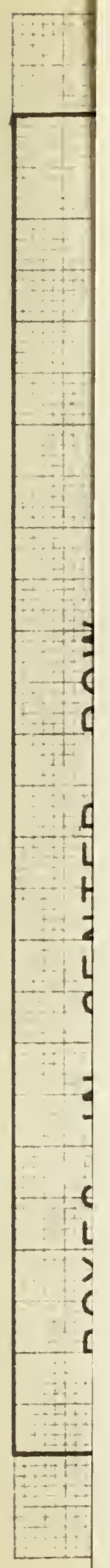



BOXES IN CENTER ROW - -

BOXES ADJACENT TO SIDEWALL

AVG RETURN AIR TEMPERATURE - 0.5 $\mathrm{F}$

TRAP DOORS

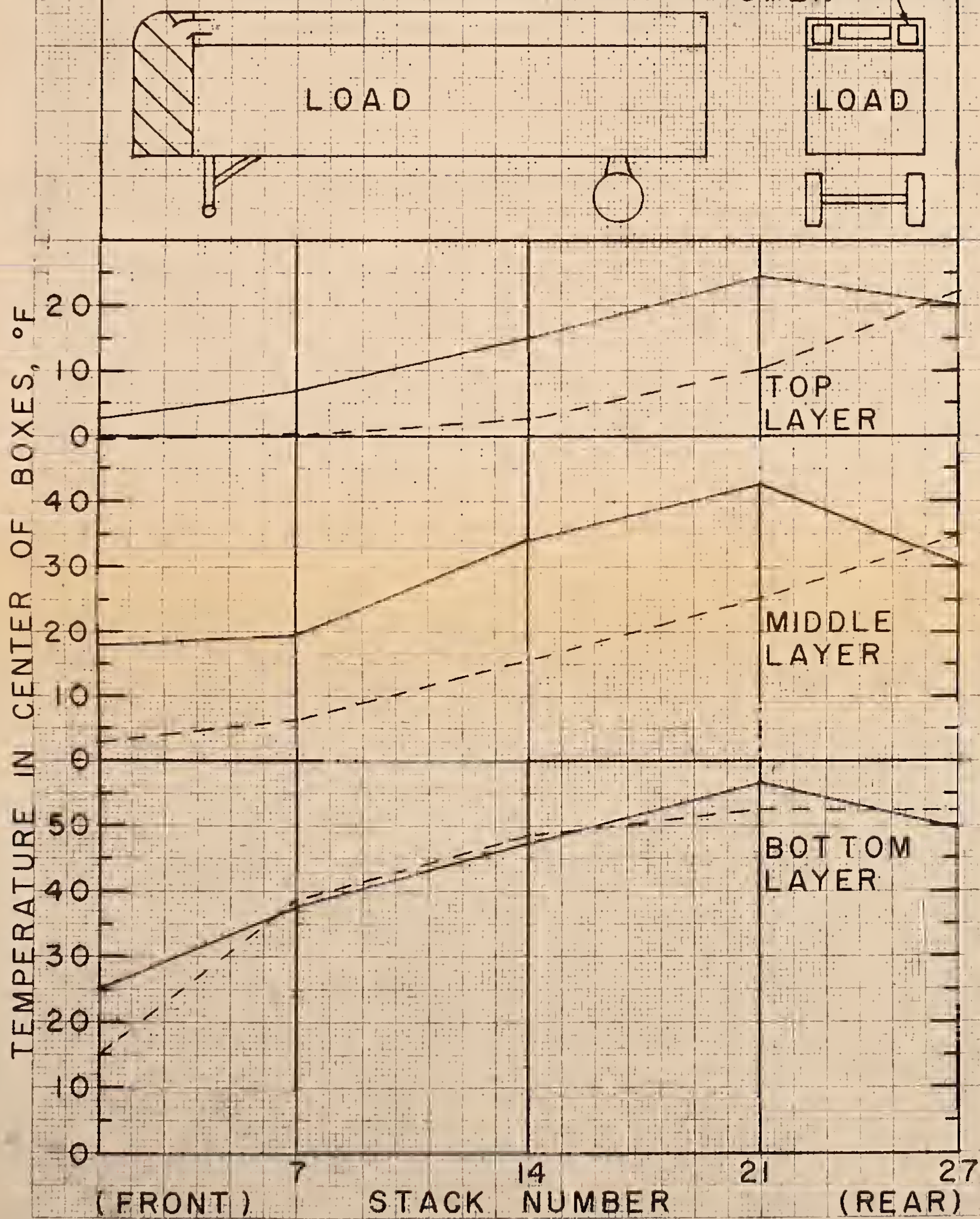
OPEN 


BOXES IN CENTER ROW - -

BOXES ADJACENT TO SHDEWALL +

AVG RFTHIRN AIR TEMPERATURE 0.7 'F

PLAN 2

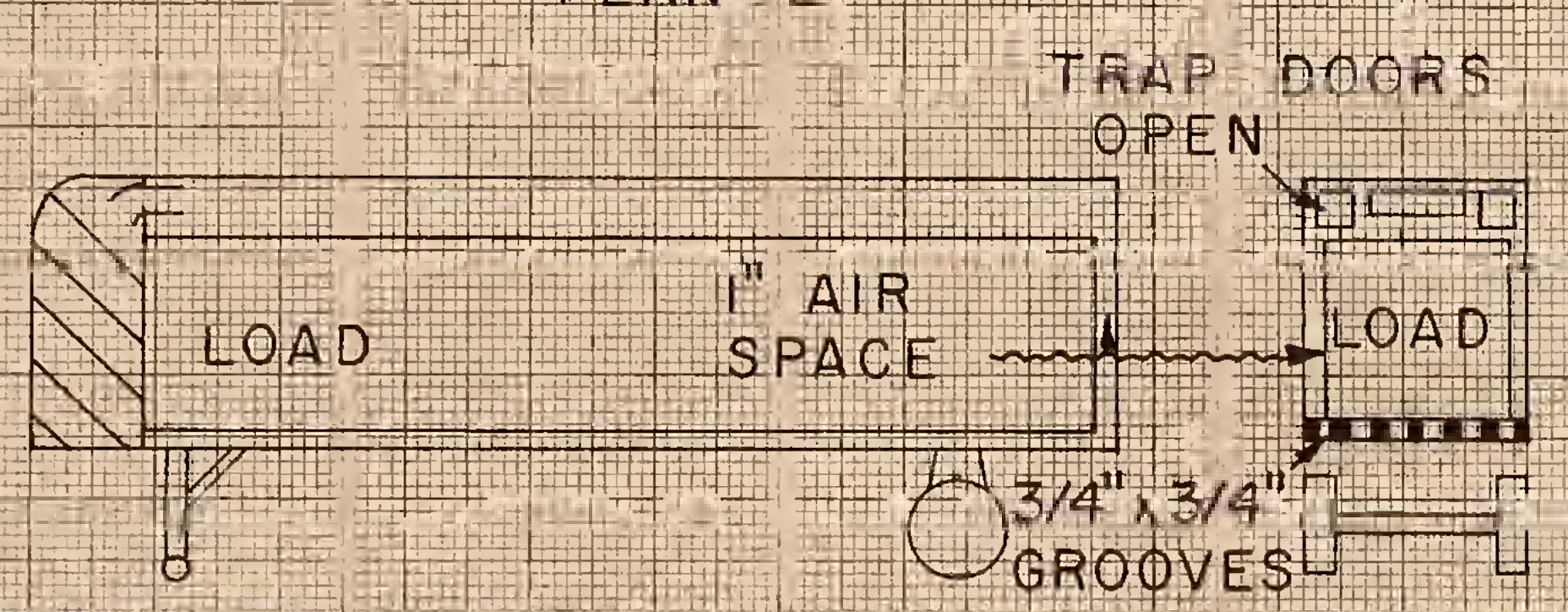

$\begin{array}{lll}10 & \\ 0 & \\ 0 & 20 \\ w & \\ x & 10 \\ 0 & \\ 0 & & 0 \\ 0 & & 0\end{array}$

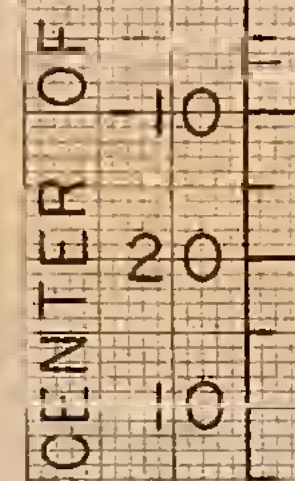

$-0$

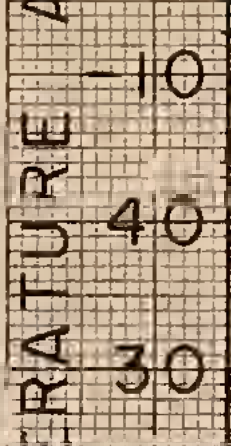

$\frac{\sum_{t=1}^{\infty} 20}{10}$

$=0$

0

7 (FRONT)
SIACK NUMBER I IREARI 


BOXES IN CENTER ROW - -

BOXES ADJAGENT TO SIDEWALL -

AVG RETURN AIR TEMPFRATURF -0.3 : OF

$$
\text { PLAN } 3
$$

TRAP EDORS GL QSED

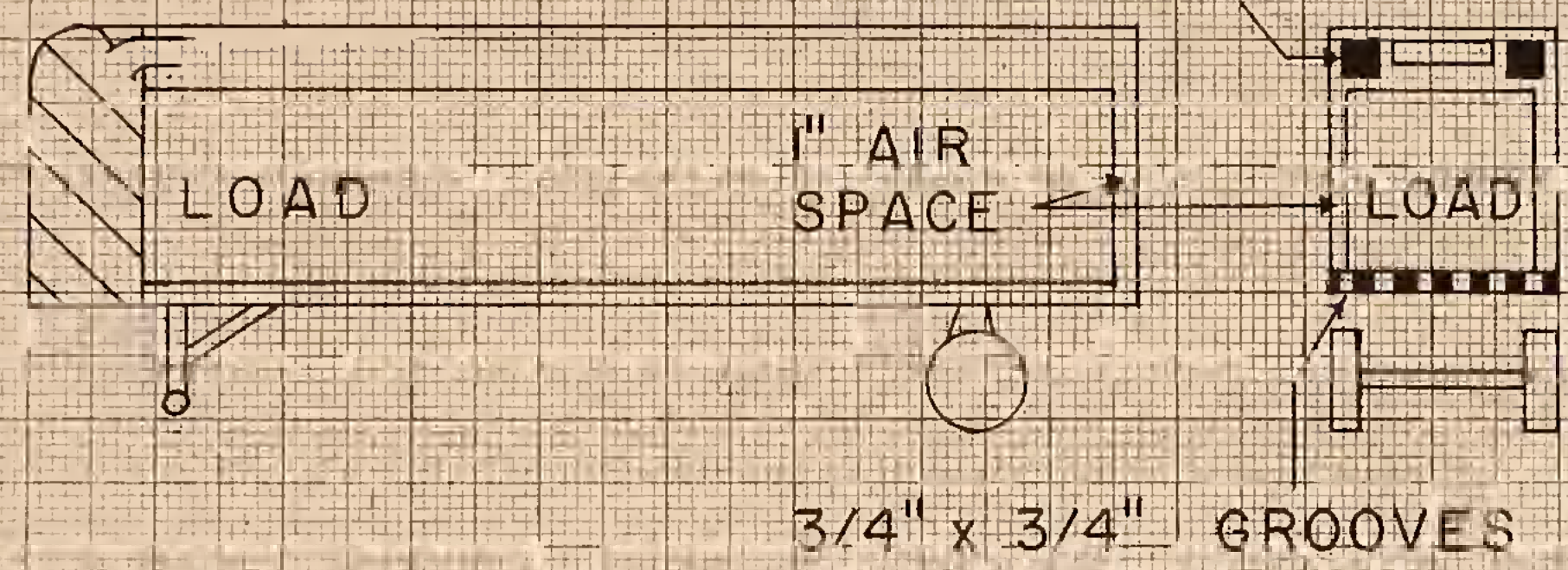

420

$\begin{array}{ll}\omega^{2} & 10- \\ 0 & \\ 0 & 0 \\ 0 & \end{array}$

$0^{-10}=$

$\begin{array}{ll} & 20 \\ \frac{r}{w} & 10 \\ \frac{1}{z} & \\ \frac{1}{0} & 0\end{array}$

$\mathrm{r}+10+$

430

$\frac{4}{2} 20$

$\frac{1}{x} 10$

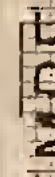

$\frac{1}{\Sigma} \quad 0$

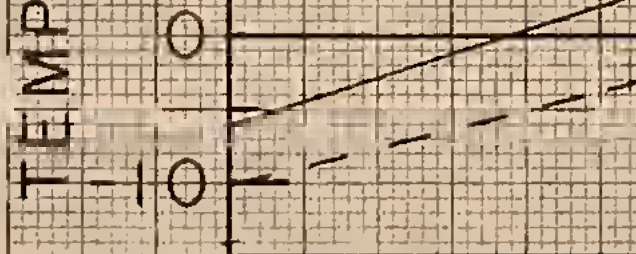

(FRONT)

7

STACK NUMBER

TOP 


BOXES IN CENTER ROW -

BOXES ADJACENT TO SIDEWALL

AVG RETURN AIR TEMPERATURE $-0.5^{\circ} \mathrm{F}$

$$
\text { PLAN } 4
$$

TRAP DOORS CLOSED AIR BAFFLE

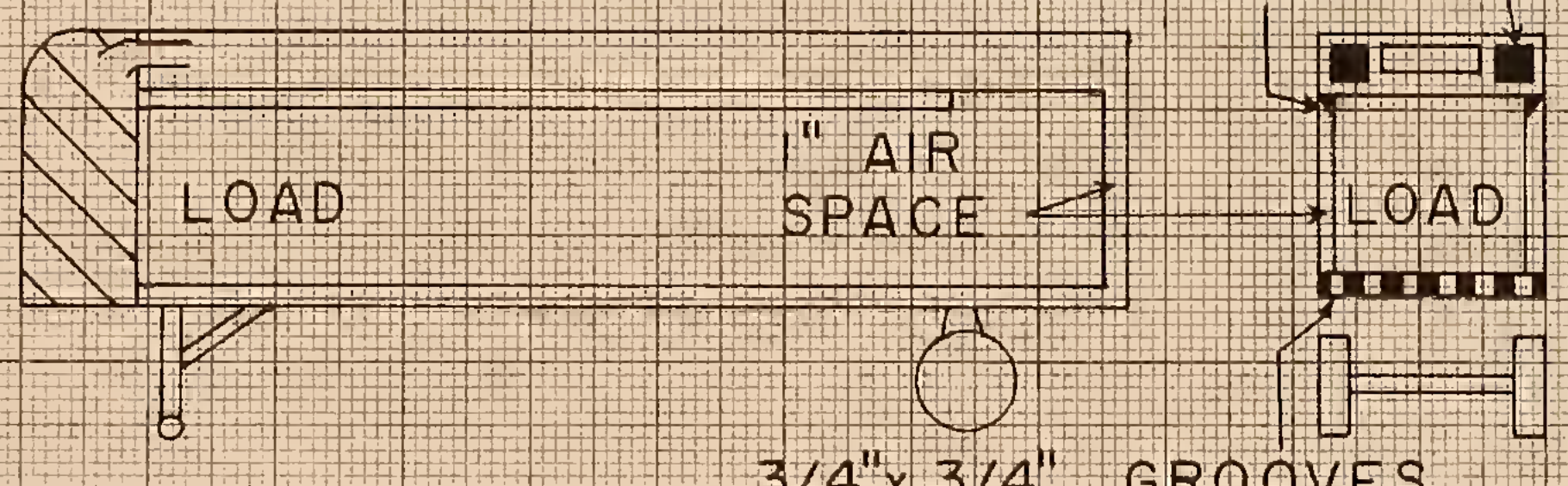

$3 / 4^{\prime \prime} \times 3 / 4^{\prime \prime}$ GROOVES

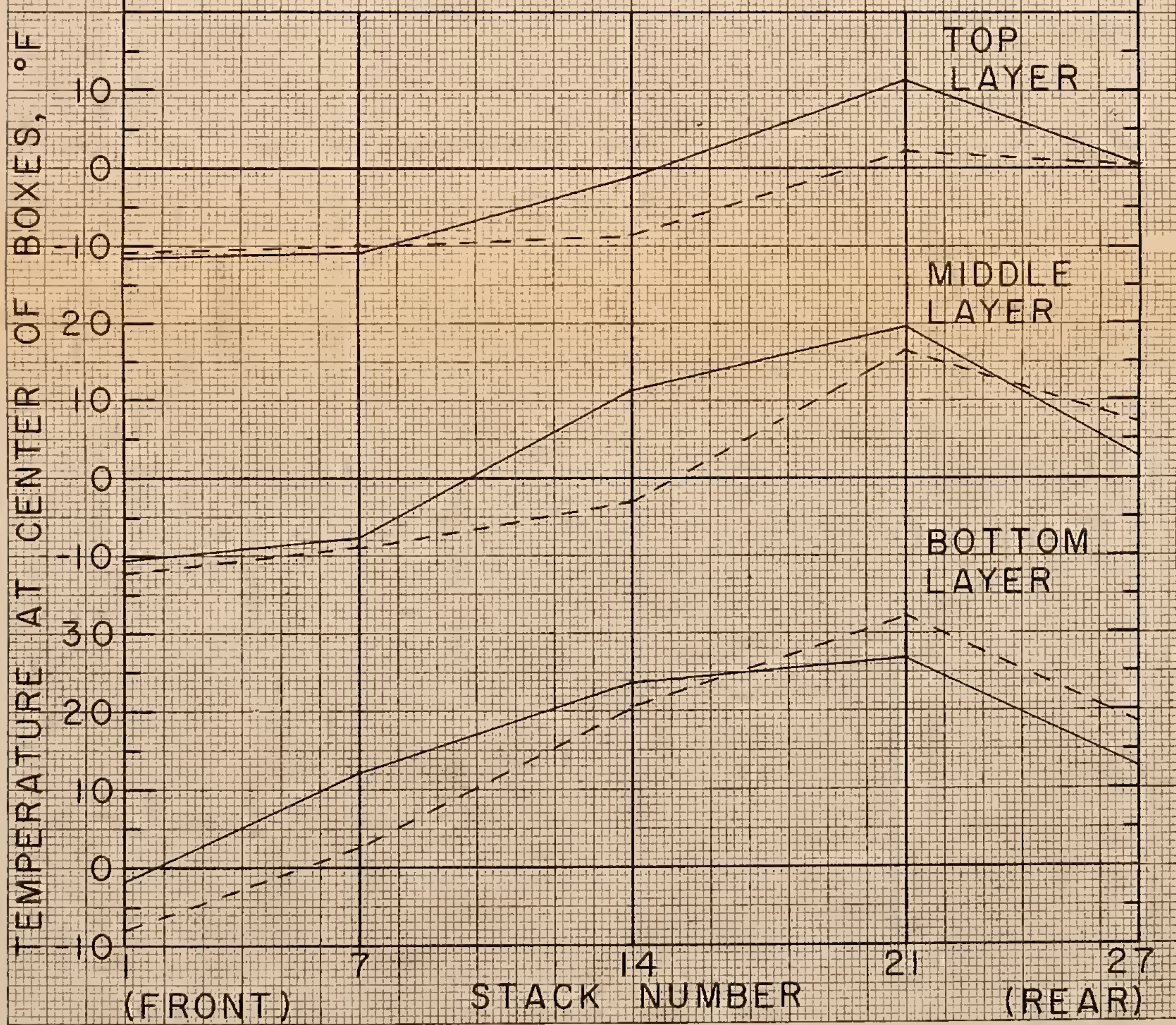




BOXES IN CENTER ROW - - -

BOXES ADJACENT TO SIDEWALL

AVG RETURN AIR TEMPERATURE $=0.5^{\circ} \mathrm{F}$

$P L A N \quad 5$

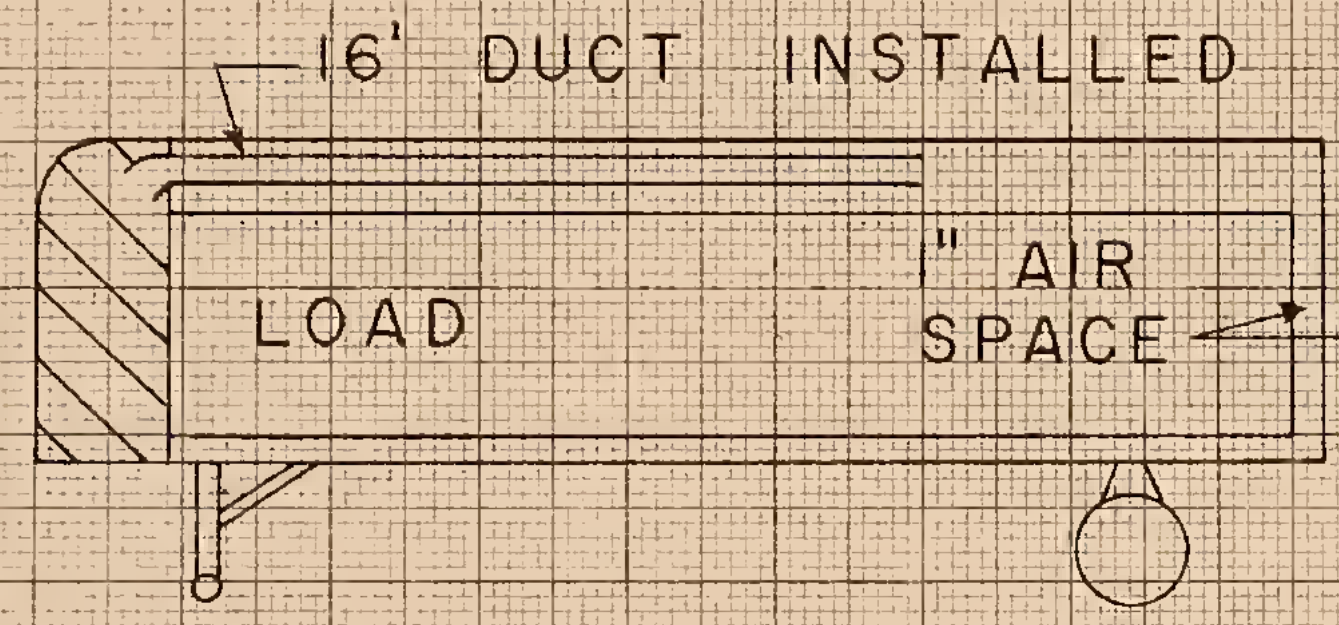

TRAP DOORS

$3 / 4^{\prime \prime} \times 3 / 4^{\prime \prime}$ GROOVES

L

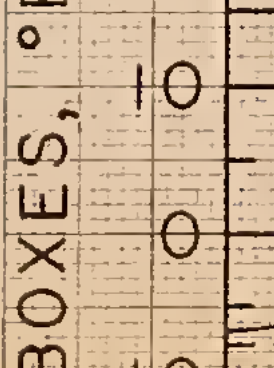

ㄴ. 20

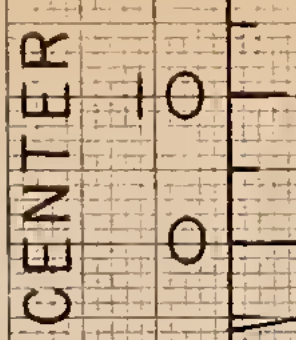

$-30$

20

$\underset{1}{\infty} 10$

$\sum 0$

$\frac{11}{1.1}-10$

(FRONT)

7

$+$

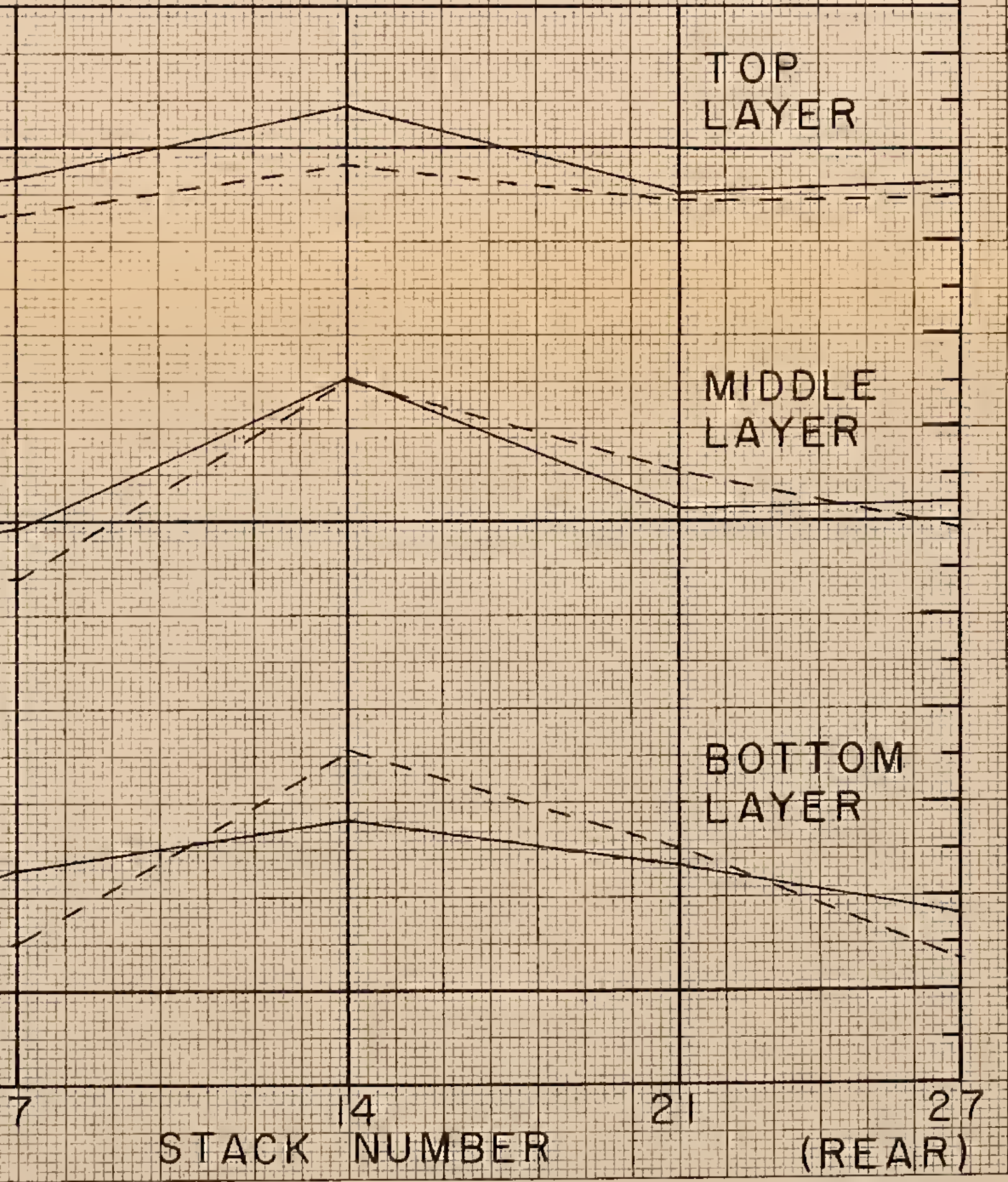




BOXES IN CENTER ROW - -

BOXES AOJACENT TO SIDEWALL

AVG RETURN AIR TEMPERATURE -0.1 ${ }^{\circ} F$

$$
P L A N=6
$$

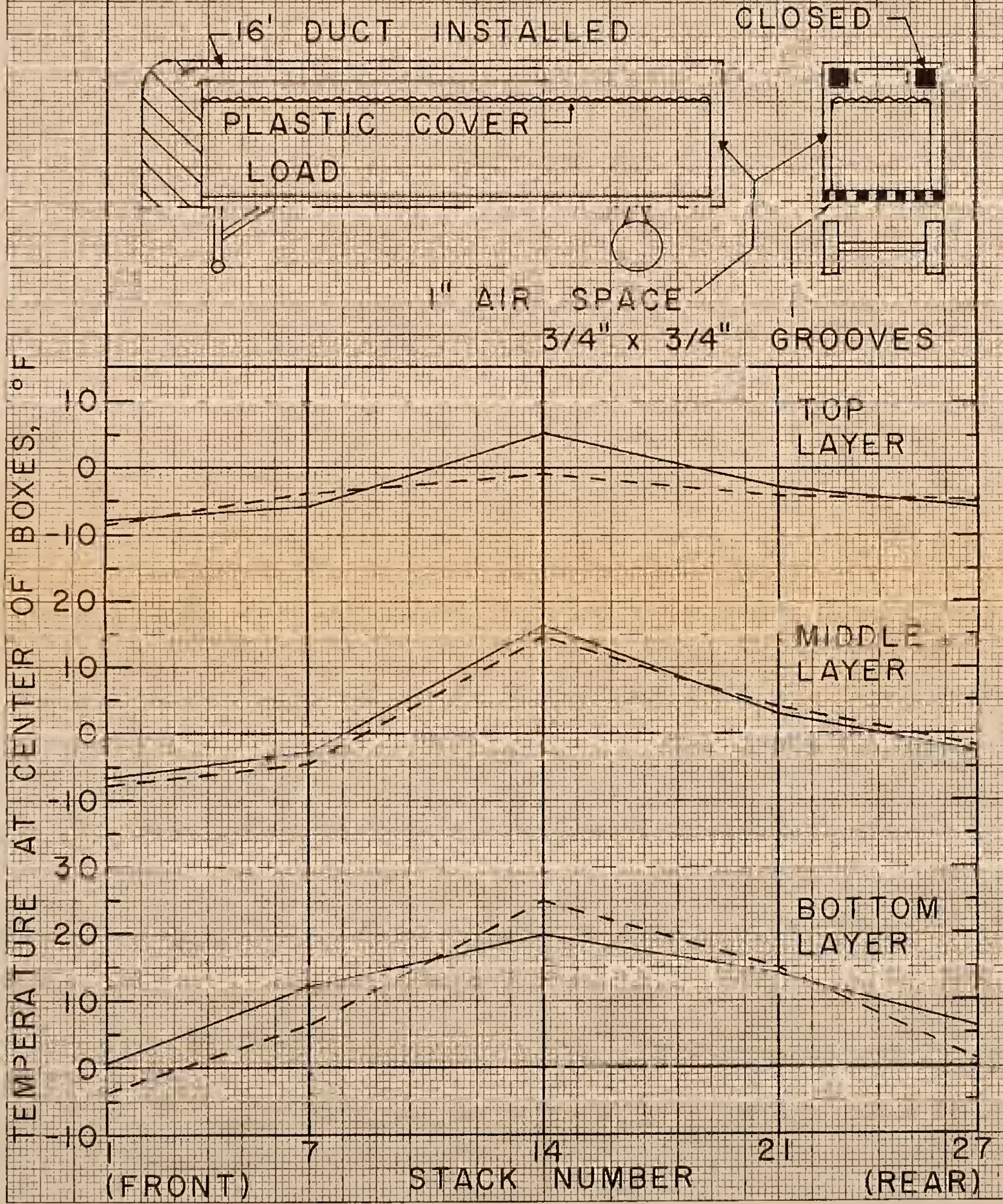

TRAP DOORS 

BOXES IN CENTER ROW - -

BOXES ADJACENT TO SIDEWALL -

AVG RETURN AIR TEMPERATURE $-1.3 \circ \mathrm{F}$

$$
\text { PLAN } 7
$$

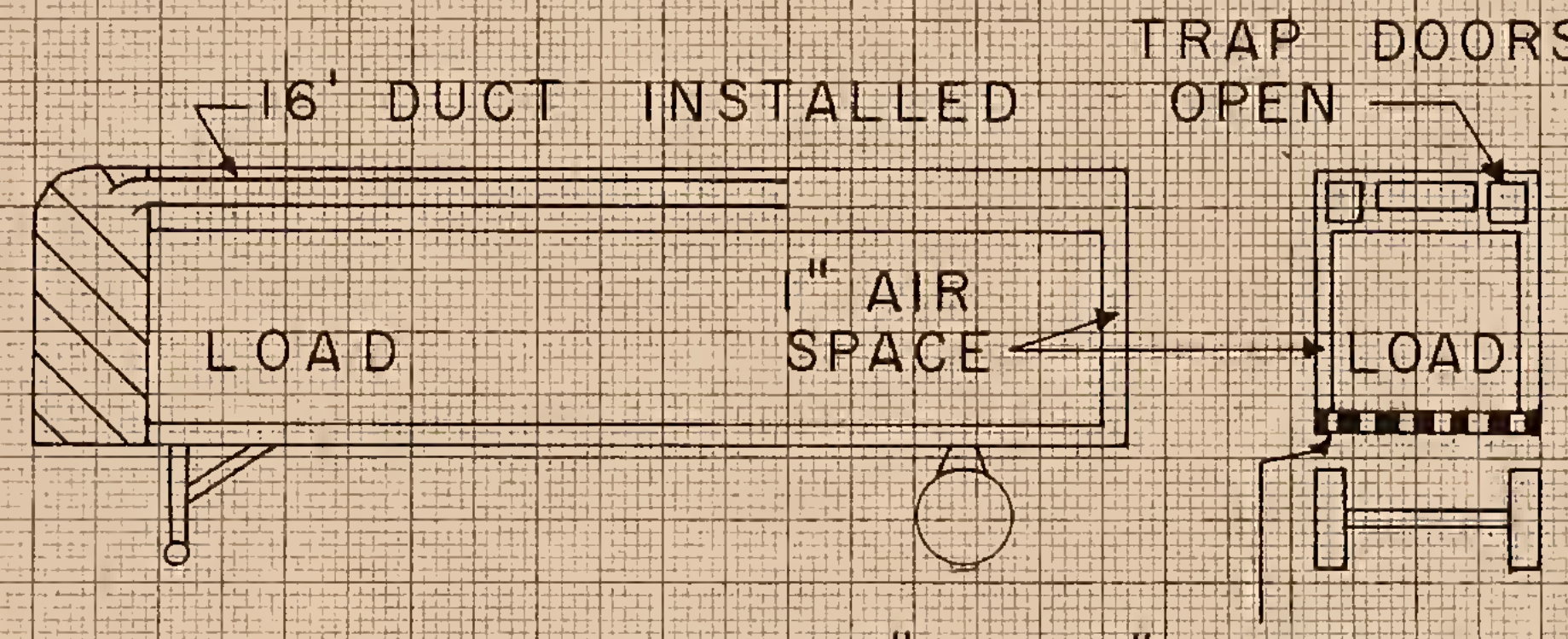

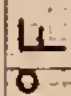

$3 / 4^{\prime \prime} \times 3 / 4^{\prime \prime}$ GROOVES

$\begin{array}{ll}\omega & 10 \\ \dot{x} & \\ 0 & 0 \\ 0 & 0\end{array} \mid$

$\frac{4}{0}-10$

$\left|\begin{array}{ll}\frac{\alpha}{4} & 20 \\ \frac{1}{E} & 10 \\ \mathbf{w} & 10 \\ 0 & 0\end{array}\right|$

${ }^{4}-10 \leq-\cdots$

$\frac{4}{5} 30$

स 20

$\frac{\Psi}{n}+10$

$\sum_{t=1}$

W

0

( $F R O N T$ )

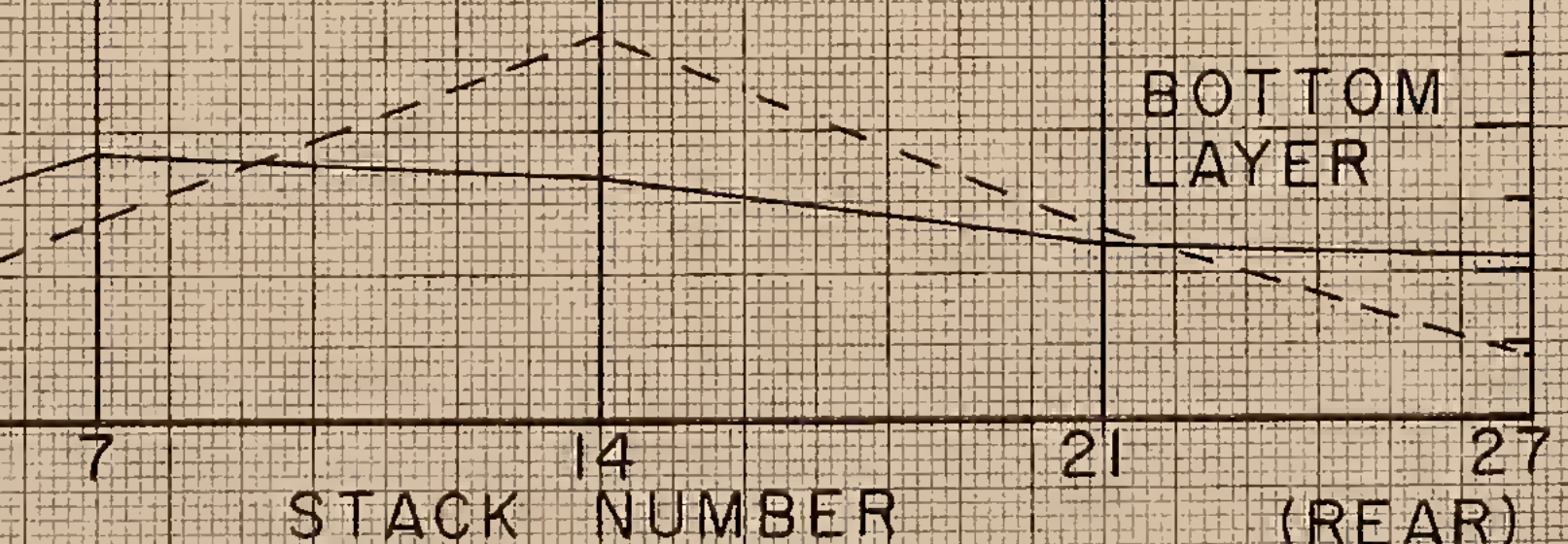




BOXES IN CENTER ROW - -

BOXES ADJACENT TO SIDEWALL

AVG. RETURN AIR TEMPERATURE $=0.9{ }^{\circ} \mathrm{F}$

$$
\text { PLAN } 8
$$

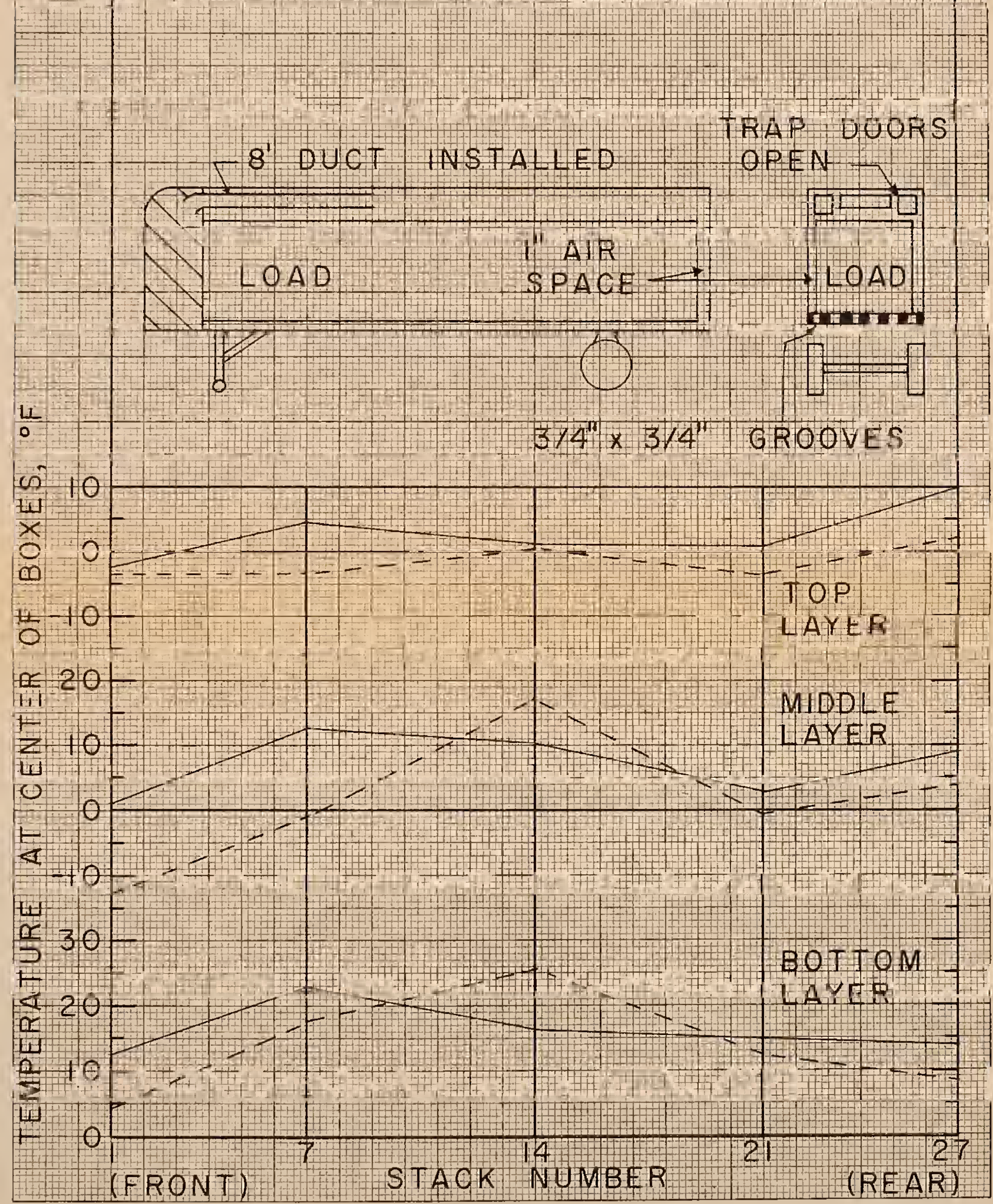





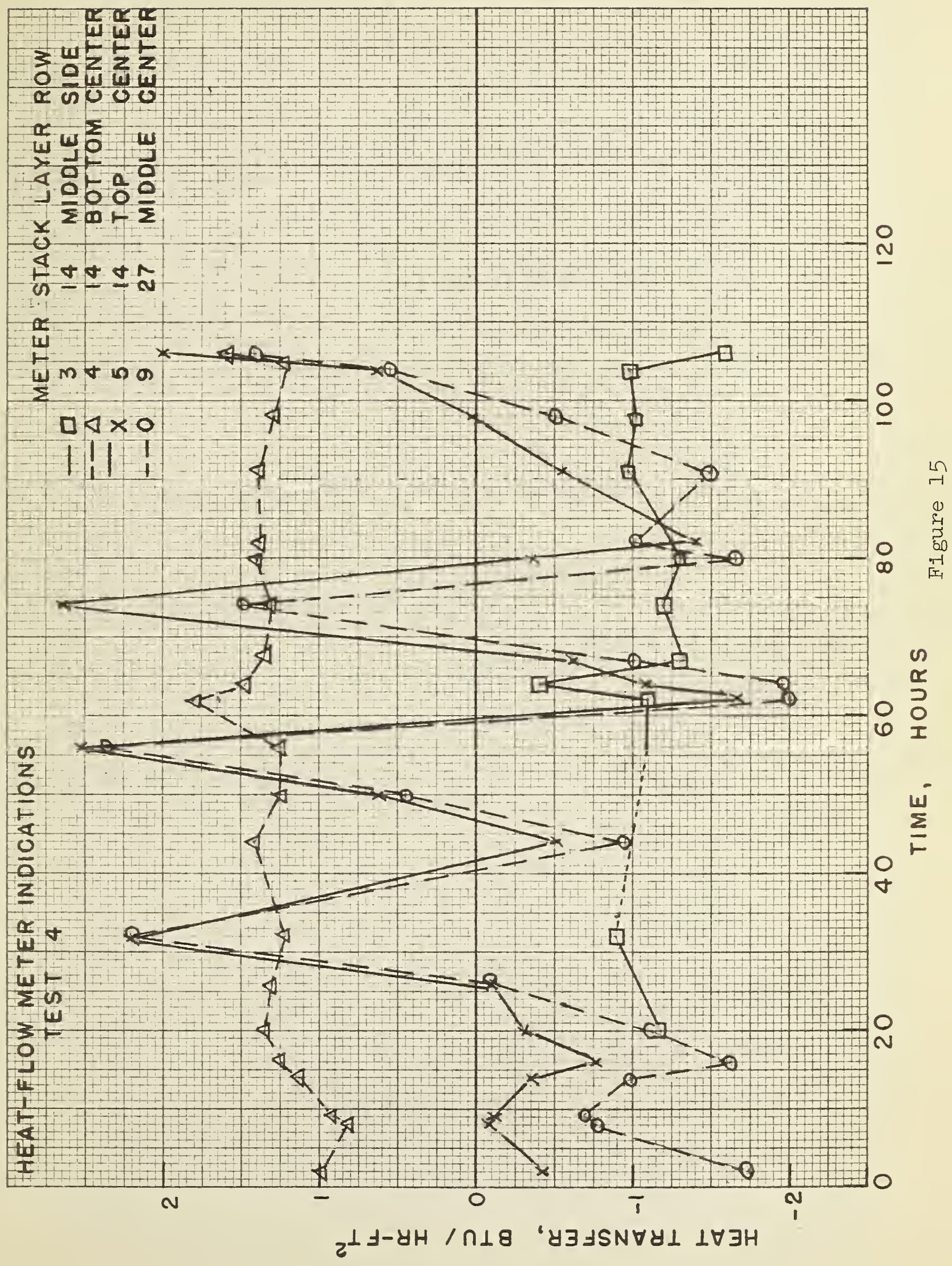





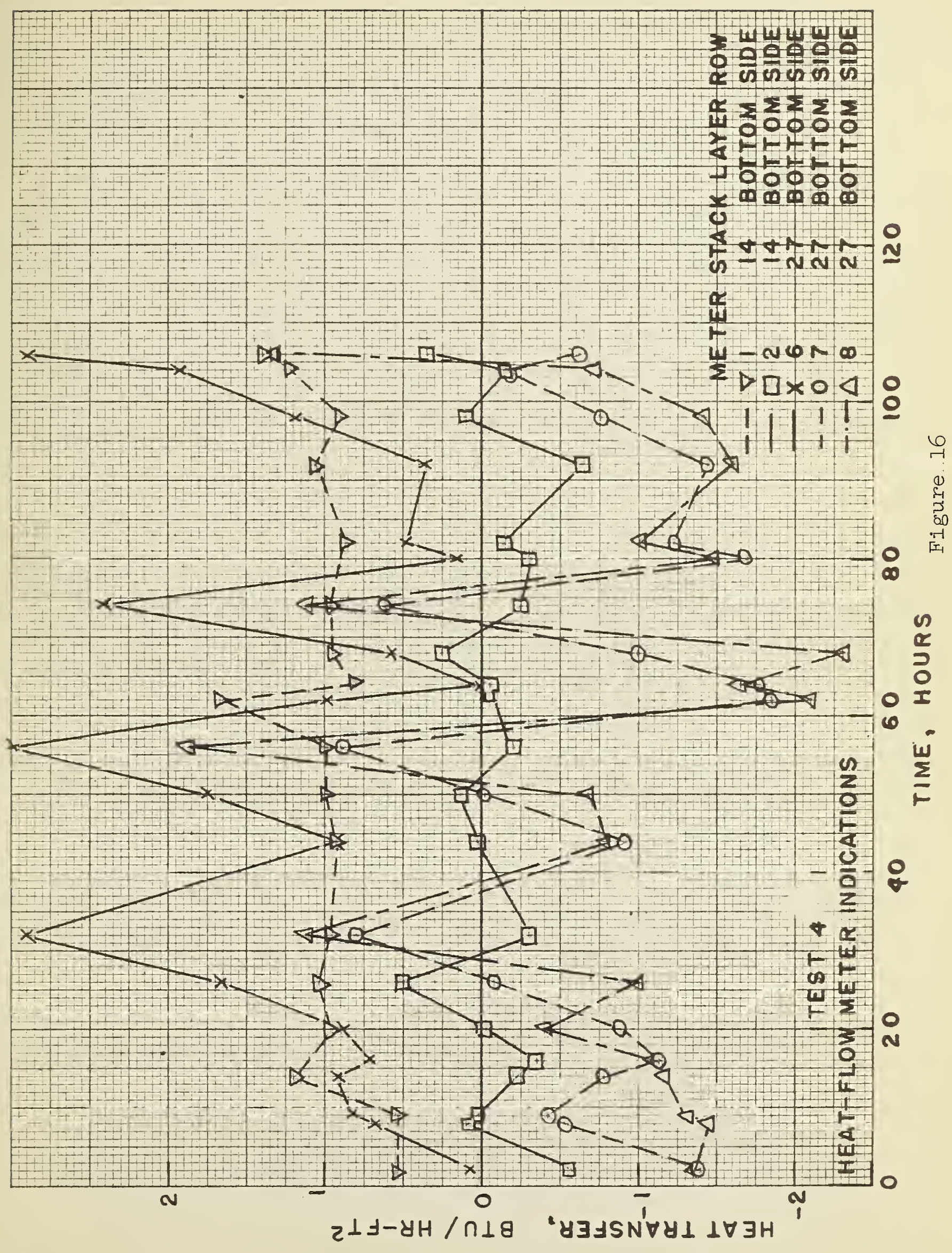





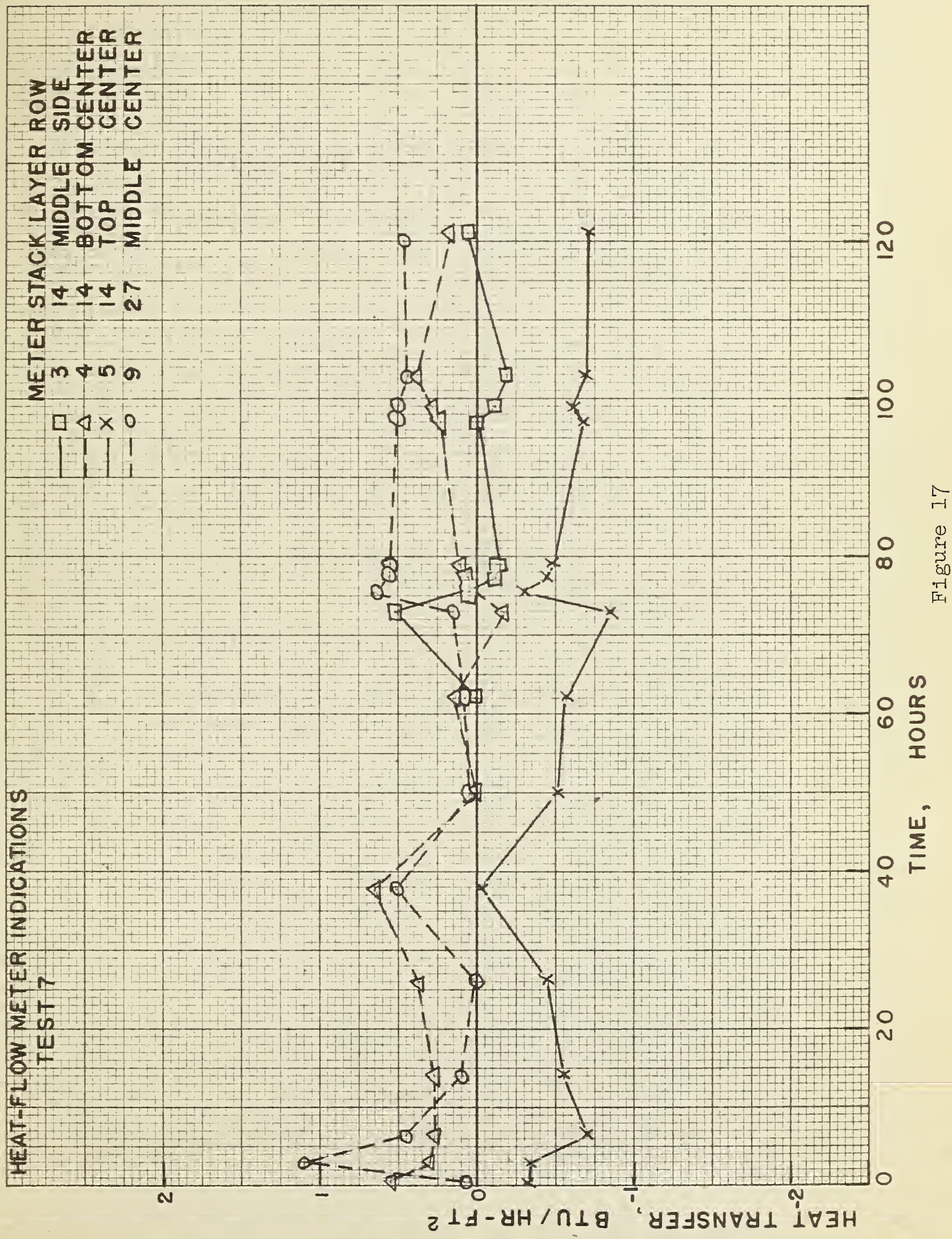





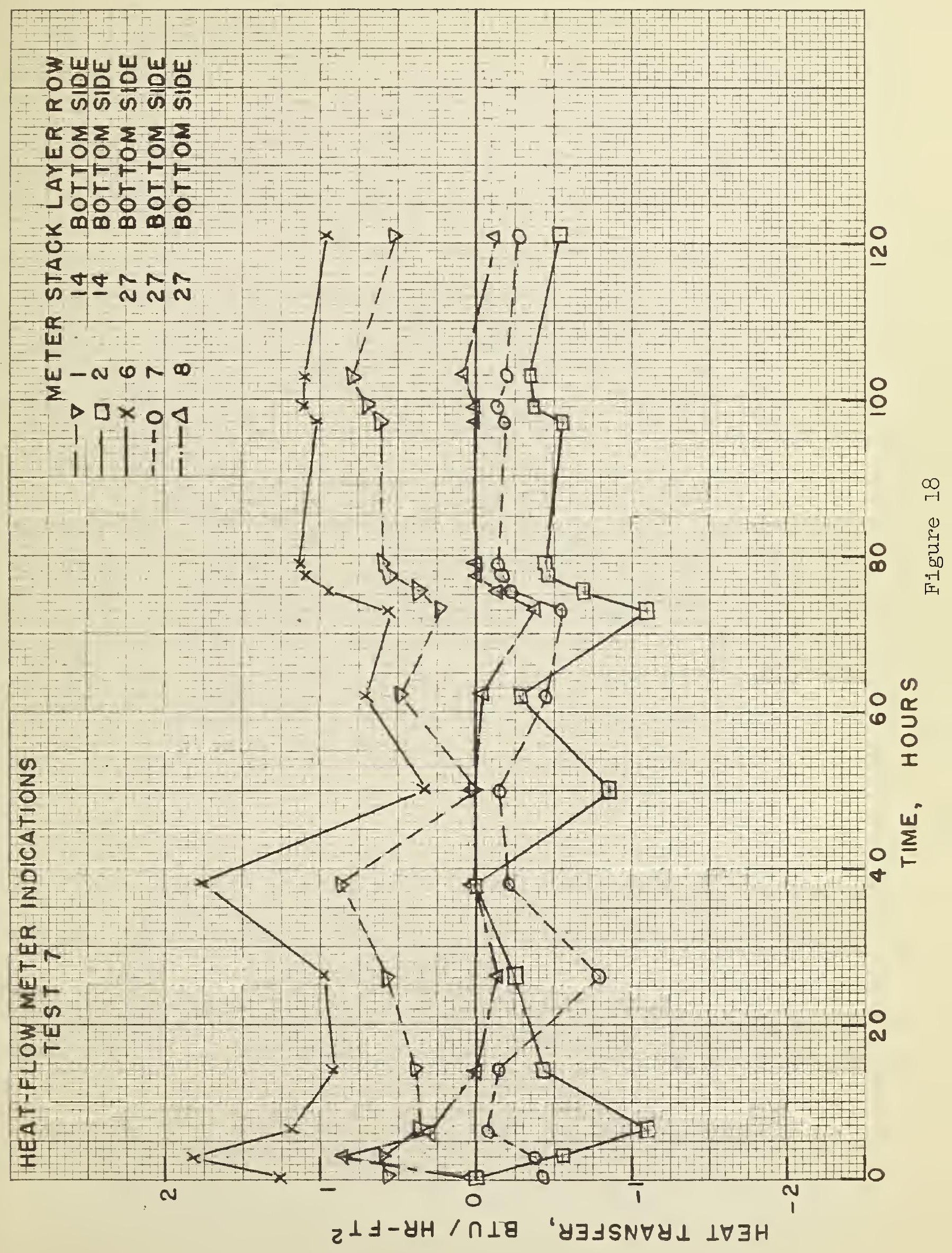



U.S. DEPARTMENT OF COMMERCE

Frederick H. Mueller, Secretary

NATIONAL BUREAU OF STANDARDS

A. V. Astin, Director

\section{THE NATIONAL BUREAU OF STANDARDS}

The scope of activities of the National Bureau of Standards at its major laboratories in Washington, D.C., and Boulder:, Colo., is suggested in the following listing of the divisions and sections engaged in technical work. In general, each section carries out specialized research, development, and engineering in the field indicated by its titlc. A brief description of the activities, and of the resultant publications, appears on the inside of the front cover.

WASHINGTON, D.C.

ELECTRICITY. Resistance and Reactance. Electrochemistry. Electrical Instruments. Magnetic Measurements. Diclectrics.

METROLOGY. Photometry and Colorimetry. Refractometry. Photographic Research. Lellgth. Engineering Metrology. Mass and Scale. Volumetry and Densimetry.

HEAT. Temperature Rhysics. Heat Measurements. Cryogenic Physics. Rheology. Molecular Kinetics. Free Radicals Research. Equation of State. Statistical Physics. Molecular Spectroscopy.

RADIATION PHYSICS. X-Ray. Radioactivity. Radiation Theory. High Energy Radiation. Radiological Equipment. Nucleonic Instrumentation. Neutron Physics.

CHEMISTRY. Surface Chemistry. Organic Chemistry. Analytical Chemistry. Inorganic Chemistry. Electrodeposition. Molecular Structure and Properties of Gases. Physical Chemistry. Thermochemistr:y. Spectrochemistry. Pure Substances.

MECHANICS. Sound. Pressure and Vacuum. Fluid Mechanics. Engineering Mechanics. Combustion Controls. OIGANIC AND FIBROUS MATERIALS. Rubber. Textiles. Paper. Leather. Testing and Specifications. Polymer Structure. Plastics. Dental Research.

METALLURGY. Thermal Metallurgy. Chemical Metallurgy. Mechanical Metallurgy. Coriosion. Metal Physics. MINERAL PRODUCTS. Engineering Ceramics. Glass. Refractories. Enameled Metals. Constitution and Miciostructure.

BUILDING RESEARCH. Structural Engineering. Fire Research. Mechanical Systems. Organic Building Materials. Corles and Safety Standards. Heat Transfer. Inolganic Building Materials.

APPLIED MATHEMATICS. Numerical Analysis. Computation. Statistical Engineering. Mathematical Pliysics.

DATA PROCESSING SYSTEMS. Components and Techniques. Digital Circuitry. Digital Systems. Analog Systems. Applications Engineering.

ATOMIC PHYSICS.' Spectroscopy. Radiometry. Mass Spectrometry. Solid State Physics. Electron Physics. Atornic Physics.

INSTRUMENTATION. Engincering Electronics. Electron Devices. Electronic Instrumentation. Mechanical Instruments. Basic Instrumentation.

Office of Weights and Measures.

BOULDER, COLO.

CRYOGENIC ENGINEERING. Cryogenic Equipment. Cryogenic Processes. Properties of Materials. Gas Liquefaction.

IONOSPHERE RESEARCH AND PROPAGATION. Low Frequency and Very Low Frequency Research. Ionosphere Rescarch. Prediction Services. Sun-Earth Relationships. Field Engineering. Radio Warning Services. RADIO IROPAGATION ENGINEERING. Data Reduction Instrumentation. Radio Noise. Tropospheric Measurcments. Tropospheric Analysis. Propagation-Tcrrain Effects. Radio-Meteorology. Lower Atmosphere Physics. RADIO STANDARDS. High frequency Electrical Standards. Radio Broadcast Service. Radio alld Microwave Materials. Atomic Frequency and Time Standards. Electronic Calibration Center. Millimeter-Wave Research. Microwave Circuit Standards.

RADIO SYSTEMS. High Frequency and Very High Frequency Research. Modulation Research. Antenna Research. Navigation Systems. Space Telecommunications.

UPPER ATMOSPHERE AND SPACE PHYSICS. Upper Atmosphere and Plasma Physics. Ionosphere and Exosphere Scatter. Airglow and Aurora. Ionospheric Radio Astronomy. 
